\title{
Targeted therapy in advanced non-small cell Check for
updates lung cancer: current advances and future trends
}

\author{
Umair Majeed, Rami Manochakian, Yujie Zhao and Yanyan Lou* (i]
}

\begin{abstract}
Lung cancer remains the leading cause of cancer-related mortality in both men and women in the US and worldwide. Non-small cell lung cancer is the most common variety accounting for $84 \%$ of the cases. For a subset of patients with actionable mutations, targeted therapy continues to provide durable responses. Advances in molecular and immunohistochemical techniques have made it possible to usher lung cancer into the era of personalized medicine, with the patient getting individualized treatment based on these markers. This review summarizes the recent advances in advanced NSCLC targeted therapy, focusing on first-in-human and early phase I/II clinical trials in patients with advanced disease. We have divided our discussion into different topics based on these agents' mechanisms of action. This article is aimed to be the most current review of available and upcoming targeted NSCLC treatment options. We will also summarize the currently available phase I/II clinical trial for NSCLC patients at the end of each section.
\end{abstract}

Keywords: Advanced NSCLC, Targeted therapy, Phase I/II clinical trials, First-in-human, Lung cancer

\section{Background}

Lung cancer remains the number one cause of cancerrelated death worldwide. Overall, lung cancer causes more deaths than breast, prostate, colorectal, and brain cancers combined [1]. In 2021, an estimated 235,760 new lung cancer cases will be diagnosed in the US, and 131,880 people will die from this disease [2]. Non-small cell lung cancer (NSCLC) is the most common type of lung cancer, accounting for more than two-thirds of the cases, with most patients (84\%) having advance disease at the time of diagnosis [3]. Identification of targetable alteration (i.e., EGFR, ALK, PI3K/AKT/mTOR, RAS-MAPK, RET, MET, BRAF, and NTRK/ROS1) in patients with advanced NSCLC has evolved its treatment paradigm [4]. The approval and adoption of agents targeting these alterations has contributed to the decline in incidence-based mortality from $35 \%$ among men with NSCLC diagnosed in 2001 to $26 \%$ among those diagnosed in 2014. Similar

*Correspondence: lou.yanyan@mayo.edu

Division of Hematology and Medical Oncology, Mayo Clinic, 4500 San

Pablo Rd, Jacksonville, FL 32224, USA patterns have been found among women with NSCLC [5]. Despite these new therapeutic options for patients with advanced NSCLC, there continues to be significant challenges as resistance development and disease progression occurs in most of these patients [6]. This has led to research in identifying drugs that can overcome these resistance pathways. Next-generation sequencing, which can be performed on the tumor tissue and circulating tumor DNA (ctDNA) in the blood, is now the standard of care for all patients with advanced NSCLC [7]. It helps in the rapid identification of actionable mutations and resistance mechanisms.

In this review after highlighting the different driver genomic alterations and their relative frequencies in advanced NSCLC we summarize the clinical efficacy and safety of FDA approved targeted therapies. We then discuss the recently published data on the first-in-human clinical trials and some of the most promising drugs in the pipeline for this disease. Literature was searched for first-in-human, phase I and phase II clinical trials in NSCLC using PubMed, Google Scholar, and the American Society of Clinical Oncology (ASCO) meeting abstracts. Each study was individually reviewed, and data original author(s) and the source, provide a link to the Creative Commons licence, and indicate if changes were made. The images or other third party material in this article are included in the article's Creative Commons licence, unless indicated otherwise in a credit line to the material. If material is not included in the article's Creative Commons licence and your intended use is not permitted by statutory regulation or exceeds the permitted use, you will need to obtain permission directly from the copyright holder. To view a copy of this licence, visit http://creativecommons.org/licenses/by/4.0/. The Creative Commons Public Domain Dedication waiver (http://creativeco mmons.org/publicdomain/zero/1.0/) applies to the data made available in this article, unless otherwise stated in a credit line to the data. 
points have been summarized. Finally, we present summary of ongoing clinical trials in a tabulated fashion at the end of each section.

\section{Predictive biomarkers in advanced NSCLC}

Predictive biomarkers in NSCLC include anaplastic lymphoma kinase (ALK) fusion oncogene, ROS proto-oncogene 1 receptor tyrosine kinase (ROS1) gene fusions, sensitizing endothelial growth factor receptor (EGFR) gene mutations, BRAF V600E point mutations, neurotrophin tyrosine kinase (NTRK) gene fusions, c-mesenchymal-epithelial transition factor (c-MET) exon 14 (METex14) skipping mutations and RET rearrangements [8]. Table 1 includes the relative frequencies and most common types of these mutations in different population subgroups along with drugs of interest. Table 2 highlights select FDA approved targeted agents with corresponding clinical trials, efficacy, and common adverse effects.

\section{EGFR inhibitors}

EGFR mutations such as exon 19 deletions (EX19del) and exon 21 (L858R) point mutations are oncogenic drivers in around $20 \%$ of patients with lung adenocarcinoma.
FDA-approved EGFR TKIs in the first-line metastatic NSCLC setting are included in Tables 1 and 2. Osimertinib is now the standard of care for untreated EGFR mutant (ex19del or L858R) advanced NSCLC due to its superior efficacy and tolerability [19].

\section{Resistance mechanisms}

Figures 1 and 2 below summarize mechanism of acquired resistance to $1^{\text {st }} / 2^{\text {nd }}$ generation TKI and osimertinib respectively. There is currently no FDA-approved target therapy for patients who have progressed after osimertinib. The standard of care is to treat such patients with chemotherapy or chemotherapy plus immunotherapy such as Impower 150 regimen. A phase 2 ORCHARD trial (NCT03944772) examines the optimal treatment for patients with EGFR mutated NSCLC depending on their underlying resistance mechanism to frontline osimertinib. Checkmate 722 (NCT02864251) is a phase III trial of nivolumab with chemotherapy or ipilimumab vs chemotherapy in EGFR-mutant, T790M-negative stage IV or recurrent NSCLC after progression on EGFR TKI therapy [20]. Similarly KEYNOTE-789 (NCT03515837) is a phase III study looking at pemetrexed-platinum with or

Table 1 Distribution of actionable mutations in advanced lung adenocarcinoma and available targeted therapies [9-18]

\begin{tabular}{|c|c|c|c|}
\hline Actionable mutation & Common Subtypes & $\begin{array}{l}\text { Frequency } \\
\text { in different } \\
\text { populations }\end{array}$ & Targeted therapies \\
\hline KRAS & G12C, G12V, G12D & $\begin{array}{l}\text { Caucasian: } 13-15 \% \\
\text { East Asian: } 3.6 \% \\
\text { Indian: } 3.9 \%\end{array}$ & KRAS G12C inhibitors: Sotorasib, Adagrasib \\
\hline EGFR & Deletion 19, L858R & $\begin{array}{l}\text { Caucasian: } 12-15 \% \\
\text { East Asian: } 47-64 \% \\
\text { Indian: } 22 \%\end{array}$ & EGFR inhibitors: Erlotinib, Gefitinib, Afatinib, Dacomitinib, Osimertinib \\
\hline ALK & EML-ALK fusion & $\begin{array}{l}\text { Caucasian: } 7 \% \\
\text { East Asians: } 5 \% \\
\text { Indian: } 3 \%\end{array}$ & $\begin{array}{l}\text { ALK inhibitors: Crizotinib, Ceritinib, Alectinib, Brigatinib, Lorlatinib } \\
\text { ALK, ROS1 and pan-TRK inhibitor: Entrectinib }\end{array}$ \\
\hline MET & $\begin{array}{l}\text { Exon } 14 \text { skipping mutation } \\
\text { MET amplification }\end{array}$ & $\begin{array}{l}\text { Caucasian: } 2.1-4.5 \% \\
\text { East Asian: } 0.9-4 \%\end{array}$ & $\begin{array}{l}\text { MET, ALK, and ROS1 inhibitor: Crizotinib } \\
\text { MET inhibitors: Capmatinib, Tepotinib }\end{array}$ \\
\hline BRAF mutations & V600E & $\begin{array}{l}\text { Caucasian: } 2.6 \% \\
\text { East Asian: } 1.7 \% \\
\text { Indian: } 1.5-3.5 \%\end{array}$ & BRAF + MEK inhibition: Dabrafenib + Trametinib \\
\hline RET & RET-KIF5B & $\begin{array}{l}\text { Caucasian: } 1-2 \% \\
\text { East Asian: } 1 \%\end{array}$ & RET inhibitors: Selpercatinib, Pralsetinib \\
\hline ROS1 & Variable fusion partners & $\begin{array}{l}\text { Caucasian:0.7-1.7\% } \\
\text { East Asian: } 0.8 \% \\
\text { Indian: } 2.8 \%\end{array}$ & Crizotinib, Ceritinib, Lorlatinib, Entrectinib, Repotrectinib, Taletrectinib \\
\hline NTRK & $\begin{array}{l}\text { NTRK } 1,2,3 \text { with different } \\
\text { fusion partners }\end{array}$ & $\begin{array}{l}\text { Caucasian: } 0.2 \% \\
\text { East Asian: } 0.3 \% \\
\text { Indian: } 0.7 \%\end{array}$ & $\begin{array}{l}\text { Pan-TRK, ALK and ROS1 inhibitor: Entrectinib } \\
\text { Pan-TRK inhibitor: Larotrectinib }\end{array}$ \\
\hline HER2 & $\begin{array}{l}\text { HER2 amplification } \\
\text { HER2 Exon } 20 \text { mutation }\end{array}$ & $\begin{array}{l}\text { Caucasian: } 2-4 \% \\
\text { East Asian:1.3\% } \\
\text { Indian: } 1.5 \%\end{array}$ & $\begin{array}{l}\text { Antibody drug conjugates: ado-trastuzumab emtansine, trastuzumab } \\
\text { deruxtecan } \\
\text { HER2 Exon } 20 \text { inhibitors: Mobocertinib, Poziotinib }\end{array}$ \\
\hline
\end{tabular}

KRAS: kirsten rat sarcoma viral oncogene homolog; EGFR: epidermal growth factor receptor; ALK: anaplastic lymphoma kinase; EML4: echinoderm microtubuleassociated protein-like 4; BRAF: v-Raf murine sarcoma viral oncogene homolog B; HER2: human epidermal growth factor receptor 2; ROS1: c-ros oncogene 1; RET: rearranged during transfection; KIF5B: kinesin family member 5B gene; MET: c-MET; NTRK: neurotrophic tyrosine receptor kinase 
Table 2 FDA approved targeted agents for advanced NSCLC with corresponding clinical trials, efficacy, and safety data

\begin{tabular}{|c|c|c|c|c|c|c|c|}
\hline $\begin{array}{l}\text { Actionable } \\
\text { mutation }\end{array}$ & $\begin{array}{l}\text { FDA approved therapy } \\
\text { (citation) }\end{array}$ & $\begin{array}{l}\text { Clinical trial } \\
\text { (phase) }\end{array}$ & Comparator & ORR (\%) & mPFS (months) & mOS (months) & Adverse effects \\
\hline KRAS & Sotorasib & CodeBreaK 100 (I) & No & $32 \%$ & 6.3 & 12.5 & $\begin{array}{l}\text { Diarrhea, nausea, } \\
\text { elevated LFT's, } \\
\text { fatigue }\end{array}$ \\
\hline \multirow[t]{5}{*}{ EGFR } & Erlotinib & EURTAC (III) & chemotherapy & $64 \%$ & 9.7 & 22.9 & $\begin{array}{l}\text { Fatigue, rash, diar- } \\
\text { rhea }\end{array}$ \\
\hline & Gefitinib & NEJ002 (III) & $\begin{array}{l}\text { Carboplatin/Pacli- } \\
\text { taxel }\end{array}$ & $74 \%$ & 10.8 & 27.2 & Rash, diarrhea \\
\hline & Afatinib & LUX-Lung 3 (III) & Cis/Pemetrexed & $56 \%$ & 11.1 & 28.2 & $\begin{array}{l}\text { Rash, diarrhea, } \\
\text { paronychia }\end{array}$ \\
\hline & Dacomitnib & ARCHER 1050 (III) & Gefitinib & $75 \%$ & 14.7 & 34.1 & $\begin{array}{c}\text { Diarrhea, paro- } \\
\text { nychia, rash }\end{array}$ \\
\hline & Osimertinib & FLAURA (III) & Erlotinib/Gefitinib & $80 \%$ & 18.9 & 38.6 & $\begin{array}{l}\text { Rash, diarrhea, } \\
\text { pneumonitis }\end{array}$ \\
\hline \multirow[t]{6}{*}{ ALK } & Crizotinib & PROFILE 1014 (III) & $\begin{array}{l}\text { Platinum/Pem- } \\
\text { etrexed }\end{array}$ & $74 \%$ & 10.9 & NR & $\begin{array}{l}\text { Vision disorder, diar- } \\
\text { rhea, edema }\end{array}$ \\
\hline & Certinib & ASCEND-4 (III) & $\begin{array}{l}\text { Platinum/Pem- } \\
\text { etrexed }\end{array}$ & $73 \%$ & 16.6 & 51.3 & $\begin{array}{l}\text { Diarrhea, nausea, } \\
\text { vomiting }\end{array}$ \\
\hline & Alectinib & ALEXALEX (III) & Crizotinib & $83 \%$ & 25.7 & Immature & $\begin{array}{r}\text { Elevated LFT's, CPK } \\
\text { elevation, anemia }\end{array}$ \\
\hline & Brigatinib & ALTA 1L (III) & Crizotinib & $74 \%$ & 24 & 47.6 & $\begin{array}{l}\text { Elevated CPK and } \\
\text { LFT's }\end{array}$ \\
\hline & Ensartinib ${ }^{\ddagger}$ & eXALT-3 (III) & Crizotinib & $75 \%$ & 25.8 & Immature & $\begin{array}{l}\text { Rash, pruritis, } \\
\text { edema }\end{array}$ \\
\hline & Lorlatinib & B7461006 (III) & Crizotinib & $76 \%$ & NR & Immature & $\begin{array}{l}\text { Hyperlipidemia, } \\
\text { edema, increased } \\
\text { weight }\end{array}$ \\
\hline \multirow[t]{2}{*}{$\begin{array}{l}\text { MET Exon } 14 \text { skip- } \\
\text { ping mutation }\end{array}$} & Capmatinib & $\begin{array}{l}\text { GEOMETRY- } \\
\text { mono-1 (II) }\end{array}$ & No & $41 \%(68 \%)^{*}$ & $5.4(12.4)^{*}$ & NA/NA & $\begin{array}{l}\text { Peripheral edema, } \\
\text { nausea }\end{array}$ \\
\hline & Tepotinib & VISION (II) & No & $46 \%$ & 8.5 & Immature & Peripheral edema \\
\hline MET amplification & Capmatinib & $\begin{array}{l}\text { GEOMETRY- } \\
\text { mono-1 (II) }\end{array}$ & No & $29 \%(40 \%)^{*}$ & $4.1(4.2)^{*}$ & NA/NA & $\begin{array}{l}\text { Peripheral edema, } \\
\text { nausea }\end{array}$ \\
\hline BRAF mutations & Dabrafenib + Trametinib & BRF113928 (II) & No & $64 \%(68 \%)^{*}$ & $\begin{array}{l}10.8 \\
(10.2)^{*}\end{array}$ & $\begin{array}{l}17.3 \\
(18.2)^{*}\end{array}$ & $\begin{array}{l}\text { Pyrexia, LFT eleva- } \\
\text { tion, HTN }\end{array}$ \\
\hline \multirow[t]{2}{*}{ RET } & Selparcatinib & LIBRETTO-001 (II) & No & $64 \%(85 \%) *$ & 16.5 (NR) & NR/NR & $\begin{array}{l}\text { Dry mouth, diar- } \\
\text { rhea, HTN }\end{array}$ \\
\hline & Pralsetinib & ARROW (II) & No & $\begin{array}{l}61 \% \\
(70 \%)^{*}\end{array}$ & $16.5(13)^{*}$ & NA/NA & $\begin{array}{l}\text { LFT elevation, } \\
\text { anemia }\end{array}$ \\
\hline \multirow[t]{4}{*}{ ROS1 } & Crizotinib & PROFILE 1001 (I) & No & $72.4 \%$ & 19.3 & 51.4 & $\begin{array}{l}\text { Vision disorder, nau- } \\
\text { sea, edema }\end{array}$ \\
\hline & Certinib & NCT01964157(II) & No & $62 \%(67 \%)^{*}$ & $9.3(19.3)^{*}$ & 24 & $\begin{array}{l}\text { Diarrhea, nausea, } \\
\text { anorexia }\end{array}$ \\
\hline & Lorlatinib & NCT01970865 (I-II) & No & $41 \%(62 \%)^{*}$ & $\begin{array}{l}8.5 \\
(21)^{*}\end{array}$ & NA & Dyslipidemia \\
\hline & Entrectinib & $\begin{array}{l}\text { STARTRK-1, START } \\
\text { RK-2, ALKA- } \\
372-001 \\
(I-I)\end{array}$ & No & $77 \%$ & 19 & NR & $\begin{array}{l}\text { Weight gain, neu- } \\
\text { tropenia }\end{array}$ \\
\hline \multirow[t]{2}{*}{ NTRK } & Larotrectinib & $\begin{array}{l}\text { LOXO-TRK-14001 } \\
\qquad(\mathrm{IIII})\end{array}$ & No & $70 \%$ & NA & NA & $\begin{array}{l}\text { LFT elevation, neu- } \\
\text { tropenia, anemia }\end{array}$ \\
\hline & Entrectinib & $\begin{array}{l}\text { ALKA, STARTRK-1, } \\
\text { STARTRK-2 (I-II) }\end{array}$ & No & $70 \%$ & NA & NA & $\begin{array}{l}\text { Dysgeusia, consti- } \\
\text { pation, fatigue }\end{array}$ \\
\hline \multirow[t]{2}{*}{ HER2 } & $\mathrm{T}-\mathrm{DM} 1^{\ddagger}$ & NCT02675829 (II) & No & $44 \%$ & 5 & NA & $\begin{array}{l}\text { Infusion reactions, } \\
\text { thrombocyto- } \\
\text { penia }\end{array}$ \\
\hline & $\mathrm{T}-\mathrm{DXd} \mathrm{d}^{\neq}$ & $\begin{array}{l}\text { DESTINY-Lung01 } \\
\text { (II) }\end{array}$ & No & $62 \%$ & 14 & NA & $\begin{array}{l}\text { Neutropenia, } \\
\text { anemia, ILD }\end{array}$ \\
\hline
\end{tabular}


Table 2 (continued)

NA: Not available, NR: Not reached

*Indicates data for treatment naïve patient

${ }^{\ddagger}$ Drugs not yet approved by FDA

${ }^{\pi}$ Citations for each trial mentioned in text or can be accessed by clicking the trial name

\section{Mechanism of resistance to 1 st/2nd generation EGF-TKI}

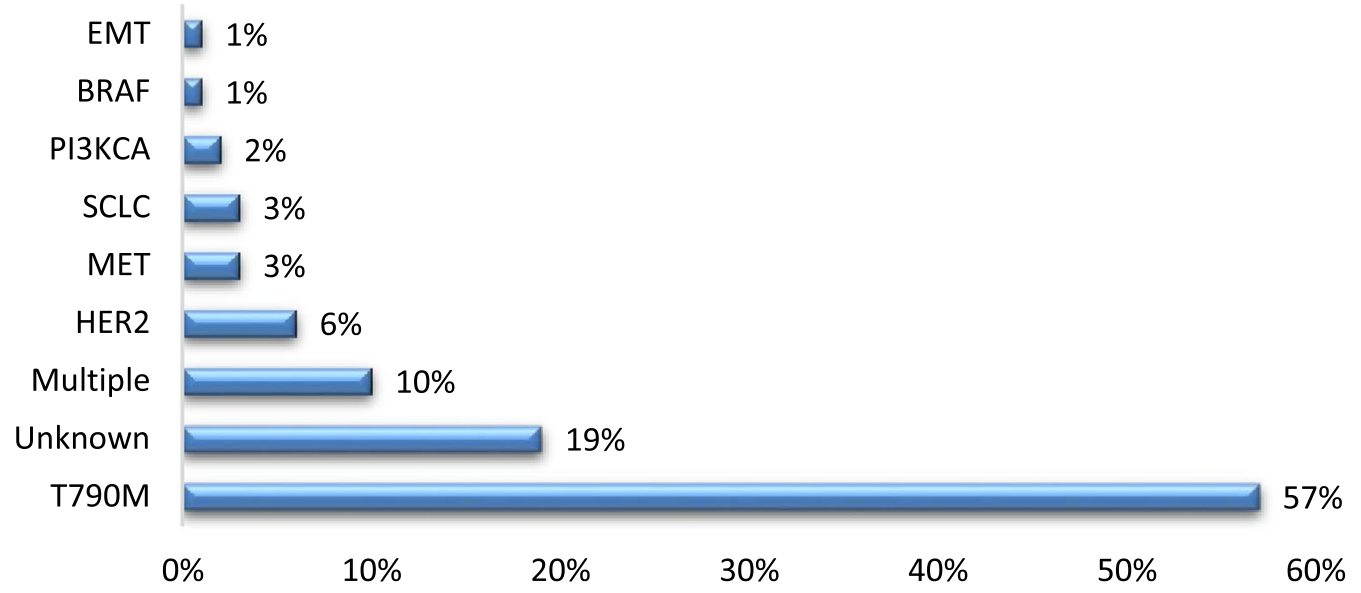

Fig. 1 Mechanisms of acquired resistance to first-generation tyrosine kinase inhibitors (gefitinib and erlotinib) [22]. EGFR, epidermal growth factor receptor; HER2, human epidermal growth factor receptor 2; MET, mesenchymal-epithelial transition factor; EMT, epithelial-mesenchymal transition; SCLC, small-cell lung cancer

\section{Mechanism of acquired resistance to Osimertinib}

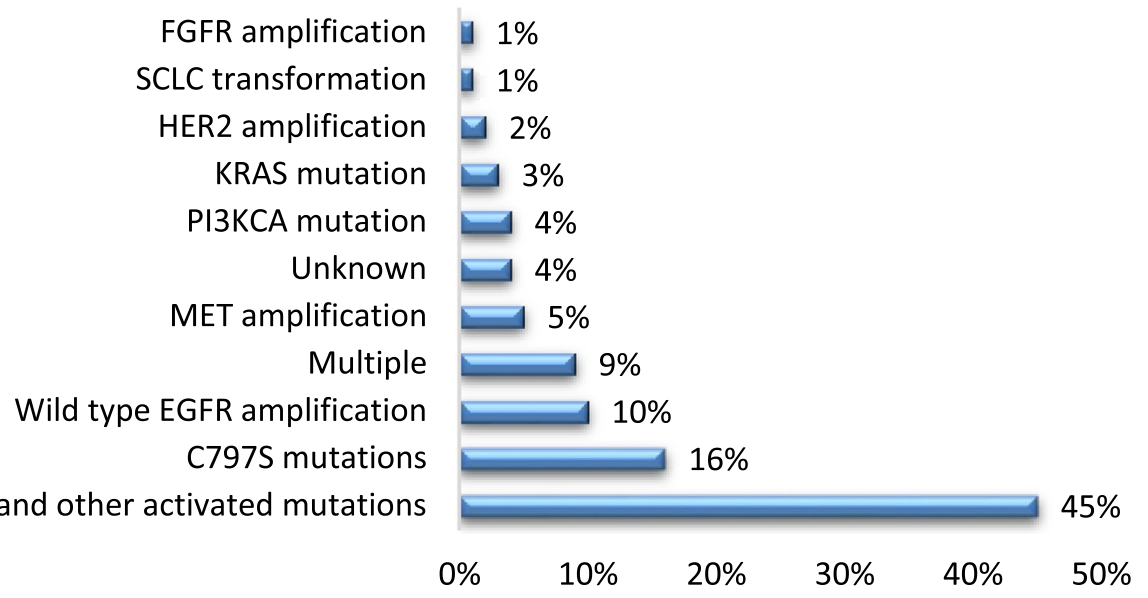

Fig. 2 Mechanisms of acquired resistance to osimertinib [22]. EGFR, epidermal growth factor receptor; MET, mesenchymal-epithelial transition factor; HER2, human epidermal growth factor receptor 2; FGFR1, fibroblast growth factor receptor 1; KRAS, Kirsten rat sarcoma viral oncogene homolog; PIK3CA, phosphoinositide-3-kinase P110a catalytic subunit; SCLC, small-cell lung cancer 
without pembrolizumab in EGFR mutated NSCLC with resistance to TKI therapy [21].

\section{Third generation EGFR inhibitors in development}

Lazertinib (YH25448) is a highly mutant selective TKI that targets EGFR mutations, including T790M. In a Phase I/II study, it was found to have an overall response rate (ORR) of $57.9 \%$ with a disease control rate of $89.5 \%$ in patients who had progression of disease on first or second-generation EGFR TKI with a defined tumor T790M mutation status. Median progression-free survival (PFS) was 11.0 months, and the median duration of response (DOR) was 15.2 months. Treatment-emergent adverse effects (TEAEs) included rash, pruritus, and paresthesia [23].

Olmutinib was studied in an open label, international phase 2 study, in patients with EGFR mutated NSCLC who failed $\geq 1$ EGFR TKIs with confirmed T790M mutation. 162 patients were enrolled from 68 sites in 9 countries. The median treatment duration was 6.5 months. Overall, $46.3 \%$ of patients had a confirmed objective response (all partial responses). The confirmed disease control rate (DCR) for all patients was $86.4 \%$. The median duration of objective response (DOR) was 12.7 months. Estimated median progression-free survival (PFS) was 9.4 months, and estimated median overall survival was 19.7 months [24].

Nazartinib (EGF816) inhibits T790M or activating mutations or both. It was studied in a phase I trial to determine the safety in 180 patients with varying EGFR mutation status and previous therapy. The recommended phase II dose was found to be $150 \mathrm{mg}$ once daily. The most common AEs were diarrhea and rash [25]. In a phase II study of treatment naïve patients with EGFRmutant NSCLC, 45 patients received $150 \mathrm{mg}$ daily of nazartinib. Overall response rate by blinded independent review committee (BIRC) was $69 \%$ with a median PFS of 18 months. Median overall survival (OS) was not evaluable and at 33 months, $56 \%$ of pts were alive. Most frequent adverse effects (AEs) were diarrhea (47\%), maculopapular rash (38\%) and pyrexia (29\%). Most frequent grade $3 / 4$ AEs were maculopapular rash and increased lipase [26]. Nazartinib is also being studied in combination with gefitinib (NCT03292133) and trametinib (NCT03516214).

Aflutinib (AST2818) has been studied in a phase IIB single-arm study in patients with EGFR T790M mutated NSCLC after progression on first/second-generation EGFR-TKIs therapy or primary EGFR T790M mutation. In 220 enrolled patients, ORR was 73.6\% (95\% CI 67.379.3) with a median PFS of 7.6 months. The most common AEs were, cough (15\%), upper respiratory infection (15\%) and AST elevation (15\%). Grade 3-5 AEs occurred in $42(19.1 \%)$ patients, the most common one was elevated $\gamma$-glutamyltransferase [27]. A phase II trial with aflutinib is currently enrolling (NCT03502850).

\section{Next generation of EGFR inhibitors}

The 4th generation of EGFR TKIs, including EAI045 and BLU-945, are currently being studied to overcome C797S which is the most significant on-target resistance mechanism to osimertinib [28]. EAI045 is the first allosteric inhibitor that targets T790M and C797S EGFR mutations. It has shown efficacy in combination with cetuximab in mouse models [29]. BLU-945 is another fourth-generation EGFR TKI that potently inhibits triple-mutant EGFR that harbors either activated L858R or exon 19 deletion mutations, plus acquired T790M and C797S mutations [28]. A Phase I/II, open-label, first-in-human (FIH) study NCT04862780 is recruiting to evaluate the safety, tolerability, pharmacokinetics (PK), pharmacodynamics (PD), and anticancer activity of BLU-945 in EGFR-mutated NSCLC who have previously received at least 1 prior EGFR-targeted TKI including those with C797S mutation.

BDTX-189 is an irreversible small-molecule inhibitor that targets oncogenic driver mutations of EGFR, HER2, and ERBB kinases [30]. Safety and preliminary efficacy from first-in-human phase I/II trial Mastery key-01 (NCT04209465) in patients with advanced solid cancers including EGFR mutant NSCLC was reported [31]. The maximum tolerated dose (MTD) for QD (fasting) was $800 \mathrm{mg}$, with $2 / 6$ pts with DLTs at $1200 \mathrm{mg}$ due diarrhea and nausea/vomiting. The most frequent $(\geq 20 \%)$ related adverse events were diarrhea ( $36 \%, 8 \% \mathrm{G} 3)$, nausea ( $28 \%$, $0 \% \mathrm{G} 3)$, and vomiting ( $25 \%, 3 \% \mathrm{G} 3)$. The rate of skin disorders was $11 \%$ with the highest severity of G2 in $1 \mathrm{pt}$.

CLN-081 (TAS6417) is a potent pan-mutation-selective EGFR inhibitor with a broad therapeutic window. Preclinical studies have shown TAS6417 as a potent inhibitor against EGFR exon 19 deletions, L858R, T790M, G719X, L861Q, S768I, and exon 20 insertion mutations [32]. It is currently being studied in a phase I/II trial in patients with EGFR exon 20 mutation (NCT04036682). Interim results for safety and efficacy were reported in 37 heavily pre-treated patients. The most common TRAEs were rash (49\%), diarrhea (24\%), paronychia (16\%), nausea (14\%), stomatitis (14\%), and dry skin (11\%). Grade 3 TRAEs included anemia (5\%), diarrhea (3\%), and increased alkaline phosphatase (ALP) (3\%). Among the 25 response evaluable pts, 10 (40\%) had a partial response (PR) and 14 (56\%) had stable disease [33].

DZD9008 is a potential EGFR TKI for NSCLC patients with EGFR or HER2 Exon20 insertion (exon20ins) and other activating mutations [34]. Two ongoing phase I/ II clinical trials (NCT03974022 and CTR20192097) are 
currently enrolling patients. Preliminary safety and efficacy results from these phase I studies of DZD9008 were presented in ASCO 2021[35]. Ninety seven NSCLC patients with EGFR or HER2 mutations were dosed (range $50 \mathrm{mg}$ to $400 \mathrm{mg}$, once daily) with DZD9008, 59 of these had EGFR exon20ins. DZD9008 was well tolerated up to $400 \mathrm{mg}$ (MTD) once daily. The DLTs were diarrhea and cardiac arrhythmia. The most common TEAEs were diarrhea (grade $3,5.2 \%$ ) and skin rash (grade 3, 1\%). In a heavily pretreated population, at the RP2D dose of $300 \mathrm{mg}$ once daily, the objective response rate was $48.4 \%$ (15/31), and disease control rate (DCR) was $90.3 \%$ $(28 / 31)[35]$.

Tarloxotinib is a prodrug of a pan-ERBB kinase inhibitor that releases a potent metabolite (Tarloxotinib-E) in hypoxic conditions. It preferentially delivers the active moiety to the tumor over normal tissues. The first analysis of RAIN-701 trial included patients with advanced NSCLC with an EGFR Exon 20 insertion (Cohort A) or HER2 activating mutation (Cohort B) with progression after platinum-containing chemotherapy. The disease control rate for all evaluable patients was $60 \%(12 / 20)$. The grade 3 TEAEs included prolonged QTc (34.8\%), rash (4.3\%), diarrhea (4.3\%), and increased ALT (4.3\%) [36]. Patients are currently being enrolled in NCT03805841.

Amivantamab (JNJ-372) is a novel, fully human antiEGFR-MET bispecific antibody which targets both EGFR and MET driven disease [37]. Preliminary results of pts with advanced NSCLC harboring exon 20 insertion (exon20ins) mutations in the ongoing CHRYSALIS study led to its accelerated approval by FDA for this subset of patients in May 2021 [38]. 50 patients with exon20ins received amivantamab. 39/50 patients were response evaluable with a median follow up of 4 months. In the response evaluable patients ORR was $36 \%$, clinical benefit rate was $67 \%$, mPFS was 8.3 months and duration of response was 10 months. The most common adverse events were rash $(72 \%)$, infusion related reactions $(60 \%)$, and paronychia (34\%). Grade $\geq 3$ were reported in $36 \%$ of the patients [37].

Poziotinib is a potent and irreversible TKI with a structure that can overcome the steric hindrance of the exon 20 limited binding pocket. In the ZENITH20 trial Poziotinib showed excellent CNS activity in patients with EGFR or HER2 exon 20 mutations with ORR of $22.2 \%$ $(8 / 36)$, DCR of $88.9 \%(32 / 36)$ and intra cranial complete response in $3 / 36$ patients [39]. A phase II trial NCT03318939 is currently recruiting advanced NSCLC with EGFR or HER2 Exon 20 Insertion Mutation.

Mobocertinib (TAK-788) is a potent oral TKI targeting EGFR ex20ins mutations and has breakthrough therapy designation in the US for post platinum based chemotherapy pts with EGFR ex20ins positive mutant
NSCLC [40]. This 3-part, open-label, multicenter study (NCT02716116) has dose-escalation/expansion and extension (EXCLAIM) cohorts. Efficacy and safety data for 114 platinum-pretreated pts (PPP) and 96 pts from EXCLAIM safety cohort was presented in ASCO 2021. Among PPP pts confirmed ORR was $28 \%$, including 1 CR. In this group the DCR was $78 \%$, median DOR was 17.5 mo. In the EXCLAIM cohort $(n=96) 49 \%$ had received $\geq 2$ prior lines. Confirmed ORR was $25 \%$, with 1 CR; DCR was $76 \%$ and median DOR was not reached. Most common TRAEs were diarrhea (91\%), rash (45\%) and paronychia (38\%). AEs leading to discontinuation in $>2 \%$ were diarrhea (4\%) and nausea (4\%) [40].

\section{EGFR therapy in combination with other targeted agents}

Amivantamab is also being evaluated in NCT02609776 clinical trial as a monotherapy or combination with Lazertinib or chemotherapy (Carboplatin/Pemetrexed) in EGFR or MET mutant/amplified NSCLC. The preliminary responses were achieved in the third generation EGFR TKI-relapsed disease, including C797S, cMet amplification, and Exon20ins disease [41]. Updated results of amivantamab and lazertinib combination in osimertinib relapsed patients with EGFR mutant NSCLC were presented in ASCO 2021. Of the 45 osimertinibrelapsed patients $36 \%$ had a confirmed response (1 complete response and 15 partial responses). At a median follow up of 8.2 months 20 out of 45 patients (44\%) remain on treatment. The mPFS was 4.9 months. An IHC-based approach identified pts most likely to benefit from the combination regimen with $9 / 10$ (90\%) IHC high (combined EGFR + MET H score $>400$ ) pts and only $1 / 10$ IHC low pts responding to treatment [42].

Osimertinib and savolitinib (MET TKI) combination was studied in a phase 1b study with advanced, METamplified, EGFR mutant NSCLC who had progressed on EGFR TKIs. It was shown to have an acceptable risk-benefit profile and encouraging anti-tumor activity in MET-amplified, EGFR mutant positive, advanced NSCLC patients [43]. Combinations using the third-generation TKI such as osimertinib and an earlier generation TKI dacomitinib is being studied (NCT03810807) in the hope to prevent different acquired EGFR alterations. In the INSIGHT 2 study, combination of osimertinib and tepotinib is being studied in patients with EGFR mutant NSCLC with acquired resistance to first line osimertinib due to MET amplification (NCT03940703) [44].

The promising synergy between EGFR and VEGFR inhibitors was seen in phase 3 RELAY study (NCT02411448), in which the addition of ramucirumab to erlotinib lead to a median PFS of 19.4 months (95\% CI 15.4-21.6) compared with 12.4 months (95\% CI 11.0 13.5) for erlotinib alone without any new adverse events 
[45]. Based on this data, the FDA approved this combination in May 2020 [46]. In a phase 2 randomized clinical trial of 81 patients with NSCLC with EGFR T790M mutation, osimertinib plus bevacizumab failed to show prolongation of progression-free survival and overall survival compared with osimertinib alone [47]. Currently there is another ongoing trial looking at the combination of osimertinib with ramucirumab (phase II; NCT03909334) [48]. Interim results from a median follow-up time of 25 months show an ORR of $76 \%$. Median DoR was 13.4 months (90\% CI 9.6-21.2 months). Median PFS was 11.0 months (90\% CI 5.5-19.3 months). Common Grade 3 or higher TRAEs were hypertension (8\%) and platelet count decreased (16\%) [49]. Table 3 summarizes current ongoing phase I/II trials with EGFR inhibitors.

\section{ALK Inhibitors}

Rearrangements in the anaplastic lymphoma kinase (ALK) are found in $3-7 \%$ of the patients in NSCLC patients [50]. Crizotinib was the first FDA-approved ALK inhibitor. Since then ceritinib, alectinib, brigatinib, and lorlatinib have been approved as detailed above in Tables 1 and 2.

First-line brigatinib evaluated against crizotinib in advanced ALK+NSCLC in the ALTA-1L trial was proven to be superior to crizotinib by BIRC-assessed PFS ( $24.0 \mathrm{v} 11.0$ months). Brigatinib was better tolerated with a delayed median time to worsening of global health status/QoL scores compared with crizotinib without any new safety concerns [51].

First-line lorlatinib was evaluated against crizotinib in a phase 3 randomized CROWN trial. ORR was $76 \%$ in the lorlatinib group vs $58 \%$ in the crizotinib group. The percentage of patients without cancer progression at 12 months was $78 \%$ in lorlatinib group as compared to $39 \%$ in crizotinib group. More grade 3 or 4 adverse events (primarily altered lipid levels) were found in lorlatinib group than crizotinib group ( $72 \%$ vs. $56 \%$ ) [52].

SAF-189 $\mathrm{s}$ is a novel selective ALK inhibitor with CNS penetration. In a phase I/II study, 36 patients with advanced ALK-positive NSCLC, 22 had CNS metastatic disease, and 26 patients had progressed on prior TKIs therapy. SAF-189 s was orally administered under fasting

Table 3 Current ongoing early phase I/II trials with EGFR inhibitors

\begin{tabular}{|c|c|c|c|c|}
\hline \multicolumn{5}{|l|}{ EGFR inhibitors } \\
\hline Drug name & Mechanism of action & Clinical trial (phase) & Study design & Disease \\
\hline Aflutinib (ASK120067) & EGFR T790M Inhibitor & NCT03502850 (1/2) & Monotherapy & $\begin{array}{l}\text { EGFR mutant NSCLC progres- } \\
\text { sion on first line therapy due to } \\
\text { T790M }\end{array}$ \\
\hline BDTX-189 & EGFR/HER2 Inhibitor & NCT04209465 (1/2) & Monotherapy & $\begin{array}{l}\text { EGFR and HER2/3 mutated solid } \\
\text { cancers }\end{array}$ \\
\hline CLN-081 (TAS6417) & Pan-EGFR Inhibitor & NCT04036682 (1/2) & Monotherapy & EGFR exon 20 mutated NSCLC \\
\hline D-0316 & EGFR T790M Inhibitor & NCT04206072 (2/3) & Monotherapy & $\begin{array}{l}\text { EX19del, L858R mutated NSCLC } \\
\text { adenocarcinoma }\end{array}$ \\
\hline Dacomitinib & Pan-EGFR inhibitor & NCT03755102 (1) & $\begin{array}{l}\text { Monotherapy or in combination } \\
\text { with Osimertinib }\end{array}$ & EGFR mutant NSCLC \\
\hline DZD9008 & $\begin{array}{l}\text { Wild type EGFR and HER2 } \\
\text { Inhibitor }\end{array}$ & NCT03974022 (1/2) & Monotherapy & EGFR/HER2 mutated NSCLC \\
\hline FCN-411 & EGFR, HER2 and HER4 Inhibitor & NCT03420079 (1/2) & Monotherapy & EGFR mutant NSCLC \\
\hline JNJ-61186372 & $\begin{array}{l}\text { Bispecific antibody binding to } \\
\text { EGFR and CMET }\end{array}$ & NCT02609776 (1) & $\begin{array}{l}\text { Monotherapy or in combination } \\
\text { with Lazertinib and Carbopl- } \\
\text { atin/Pemetrexed }\end{array}$ & $\begin{array}{l}\text { EGFR or MET mutant/amplified } \\
\text { NSCLC }\end{array}$ \\
\hline Nazartinib (EGF816) & $\begin{array}{l}\text { Irreversible selective mutant } \\
\text { specific EGFR Inhibitor }\end{array}$ & NCT03292133 (2) & Combination with Gefitinib & EGFR mutant NSCLC \\
\hline Nazartinib (EGF816) & $\begin{array}{l}\text { Irreversible selective mutant } \\
\text { specific EGFR Inhibitor }\end{array}$ & NCT03516214 (1) & Combination with Trametinib & $\begin{array}{l}\text { EGFR mutant (del19 or p.L858R) } \\
\text { NSCLC }\end{array}$ \\
\hline Necitumumab & Anti EGFR mAB & NCT02496663 (1) & Combination with Osimertinib & EGFR mutant NSCLC \\
\hline Osimertinib & Potent mutant EGFR Inhibitor & NCT03434418 (2) & Monotherapy & $\begin{array}{l}\text { NSCLC with uncommon EGFR } \\
\text { mutations (EGFR 18;G719X, } \\
\text { EGFR 20;S7681, EGFR 21;L861Q) }\end{array}$ \\
\hline Tarloxotinib & $\begin{array}{l}\text { Hypoxia activated prodrug (TH- } \\
\text { 4000) wild type EGFR Inhibitor }\end{array}$ & NCT03805841 (2) & Monotherapy & $\begin{array}{l}\text { EGFR exon } 20 \text { and HER2 activating } \\
\text { mutant NSCLC }\end{array}$ \\
\hline WSD0922-FU & EGFR/EGFRvIII Inhibitor & NCT04197934 (1) & Monotherapy & EGFR mutant NSCLC \\
\hline ZN-e4 (KP-673) & EGFR Inhibitor including T790M & NCT03446417 (1/2) & Monotherapy & EGFR mutant NSCLC \\
\hline
\end{tabular}


condition at doses ranging from 20-210 mg once daily in a 21-day cycle. All 34 in efficacy analysis set achieved tumor shrinkage, with 17 confirmed PR (50\%) and 4 unconfirmed PR (11.7\%) [53]. The most common drugrelated events were nausea (38.9\%), vomiting (27.8\%) and QT prolongation (25.0\%). Only one DLT of grade 3 blood glucose increase occurred at $210 \mathrm{mg}$ [53].

TQ-B3101 inhibits ALK, ROS1, and MET. In a phase I study, 27 lung cancer patients (19 ALK +, 6 ROS1 +, 2 MET amplified) patients were enrolled. ORR was $87.5 \%$ in the $350 \mathrm{mg}$ bid cohort (7/8). In 8 patients with brain metastasis, ORR was $62.5 \%(5 / 8)$. The most common grade 3 adverse effects were neutropenia (20\%) and ALT increase (6.67\%) [54]. Currently, TQ-B3101 is studied in a phase 2 trial in subjects with ALK-positive NSCLC that have progressed on crizotinib (NCT04056572).

TPX-0131 is a next generation ALK inhibitor that can bind completely within the ATP binding boundary to overcome a variety of ALK resistant mutations, especially SFM G1202R and compound mutations L1196M/ G1202R. TPX-0131 is more than 100-fold more potent against G1202R than lorlatinib in cell proliferation assays [55]. It is currently being evaluated in a phase I/II trial (NCT04849273) in patients with ALK+advanced or metastatic NSCLC.

Ensartinib (X-396) is a highly selective and potent ALK inhibitor. The interim analysis of phase III eXalt3 study (NCT02767804) comparing ensartinib to crizotinib was recently presented. Median PFS was 25.8 months with ensartinib vs 12.7 months with crizotinib [56].

Safety and efficacy of crizotinib was studied in combination with bevacizumab in ALK/ROS-1/c-MET positive NSCLC in an open label, single arm, prospective study. The median PFS and DOR of the patients with ALK rearrangement were 13.9 and 14.8 months respectively. The most two common treatment-related adverse events were fatigue (28.6\%) and rash (21.4\%) [57].

Brigatinib in combination with bevacizumab (NCT04227028) and alectinib in combination with cobimetinib (NCT03202940) are currently under investigation.

The National Cancer Institute's ALK Master Protocol (NCT03737994) will prospectively match patients to appropriate ALK TKIs based on the underlying ALKresistance mutation. Table 4 summarizes the ongoing phase I/II clinical trials involving ALK inhibitors in patients with advanced NSCLC.

\section{MET inhibitors}

C-MET is a hepatocyte growth factor (HGF) receptor that is involved in cell survival and proliferation. Oncogenic mutations in MET include MET exon 14 skipping mutations (3-4\% of NSCLC adenocarcinomas), MET gene copy number (GCN) gain or amplification, and MET protein overexpression. These patients generally have poor responses to immunotherapy, even if the expression of PD-L1 is high [58]. There are currently two FDA-approved MET inhibitors that can be used as firstline therapy in metastatic NSCLC with MET exon 14 skipping mutations detailed above in Table 2.

FDA has approved capmatinib as the first-line in patients with MET exon 14 skipping mutations based on the GEOMETRY mono-1 trial [59]. Capmatinib has also shown activity in patients with high-level MET amplification $(G C N \geq 10)$ in treatment naive patients [60]. Updated results from the GEOMETRY mono-1 study in treatment naïve MET exon 14-mutated advanced NSCLC (cohort 7 and cohort 5b) were presented in ASCO 2021 [61]. The median PFS was 10.8 months and median OS was 20.8 months. $98.4 \%$ of pts reported AEs $(68.6 \%$ Grade 3/4) regardless of causality and $16.1 \%$ reported

Table 4 Current ongoing early phase I/II trials with ALK inhibitors in advanced NSCLC

\begin{tabular}{|c|c|c|c|c|}
\hline \multicolumn{5}{|c|}{ ALK inhibitors } \\
\hline Drug name & Mechanism of action & Clinical trial (Phase) & Study design & Disease \\
\hline Alectinib & ALK inhibitor & NCT03202940 (1/2) & Combination with Cobimetinib & $\begin{array}{l}\text { Advanced ALK rearranged NSCLC with } \\
\text { progression on Alectinib }\end{array}$ \\
\hline Brigatinib & Dual ALK and EGFR inhibitor & NCT02706626 (2) & Monotherapy & $\begin{array}{l}\text { Advanced ALK rearranged NSCLC with } \\
\text { progression on ALK inhibitors }\end{array}$ \\
\hline Brigatinib & Dual ALK and EGFR inhibitor & NCT04227028 (1) & Combination with Bevacizumab & $\begin{array}{l}\text { Advanced ALK rearranged NSCLC with } \\
\text { progression on ALK inhibitors }\end{array}$ \\
\hline Ensartinib & Selective ALK inhibitor & NCT04415320 (2) & Monotherapy & Advanced ALK rearranged NSCLC \\
\hline TPX-0131 & ALK inhibitor & NCT04849273 (1/2) & Monotherapy & $\begin{array}{l}\text { Advanced ALK rearranged NSCLC with } \\
\text { progression on at least one prior } 2^{\text {nd }} \\
\text { or } 3^{\text {rd }} \text { gen ALKTKI }\end{array}$ \\
\hline TQ-B3139 & Multi-target inhibitor of MET/ALK/ROS & NCT04056572 (2) & Monotherapy & $\begin{array}{l}\text { Advanced ALK rearranged NSCLC with } \\
\text { progressive disease on Crizotinib }\end{array}$ \\
\hline
\end{tabular}


AEs leading to discontinuation. The most common AEs were peripheral edema (54.2\%), nausea (45.0\%), vomiting (28.2\%) and increased blood creatinine (26.5\%) [61].

Tepotinib, a highly selective MET inhibitor, is being evaluated in a phase II trial NCT02864992. In VISION trial, a total of 152 patients had received tepotinib, with 99 patients being followed for at least 9 months. ORR was $46 \%$ (95\% confidence interval [CI], 36 to 57), with a median duration of response of 11.1 months $(95 \% \mathrm{CI}$ 7.2-could not be estimated). Tepotinib also demonstrated robust activity in pts with METex14 skipping NSCLC with metastatic brain disease [62]. Adverse events of grade 3 were reported in $28 \%$ of the patients, including peripheral edema in 7\% [63]. FDA granted accelerated approval to tepotinib in February 2021 based on the above data. Tepotinib was also evaluated in patients with advanced NSCLC with MET amplification by liquid biopsy, MET gene copy number $\geq 2.5$. Among 24 enrolled patients the ORR was $42 \%$ with no new safety signals [64].

Sym015, a mixture of 2 humanized antibodies, triggers MET degradation. In a sym015-01 phase I/II trial, safety and efficacy were studied in patients with MET exon 14 deletion $(n=12)$ or MET amplification $(n=8)$. Of 20 NSCLC pts, 5 had confirmed PR, and 11 had SD (DCR 80\%; 6/8 METAmp and 5/12 METEx14 $\Delta$ ). In the safety arm with 45 patients, grade 3 or above treatment-related adverse events were reported in $13.3 \%$ pts [65].

Glumetinib is a selective MET inhibitor that was well tolerated in advanced NSCLC with MET alterations at doses up to $400 \mathrm{mg}$ once daily. A phase I trial continues to enroll patients (NCT03466268).

APL-101 is a highly selective small-molecule c-Met inhibitor that targets the c-Met-dysregulated pathway in several tumors [66]. A phase I/II, multicenter, global trial, recruits patients with c-MET exon 14 skipping mutations and c-met dysregulation (NCT03175224).

REGN5093 is a human bispecific antibody that binds to two distinct epitopes of MET, blocking HGF binding and inducing MET's internalization and degradation [67]. A Phase I/II, first-in-human, multicenter study investigates the safety, tolerability, pharmacokinetics (PK), and efficacy of REGN5093 in patients with METaltered advanced NSCLC who have received all available approved therapies (NCT04077099). Table 5 summarizes the ongoing phase I/II clinical trials involving MET inhibitors in patients with advanced NSCLC.

\section{RET inhibitors}

RET gene rearrangements are found in 1-2\% of NSCLC adenocarcinomas and are mutually exclusive with EGFR, ALK, or RAS mutations [68]. NSCLC with RET fusion is associated with a high risk of brain metastasis [69]. Cabozantinib and vandetanib were previously used with modest benefit and significant toxicity. However, selpercatinib and pralsetinib have recently been approved by the FDA after promising phase II clinical trial results (Table 1).

Selpercatinib (LOXO-292) is a highly selective smallmolecule inhibitor of RET kinase approved by the FDA to treat NSCLC with RET fusion. In a phase II trial of 105 patients pretreated with platinum-based chemotherapy, the ORR was $64 \%$ (95\% confidence interval [CI], 54\% to $73 \%$ ) with a median duration of response of 17.5 months. Among the 39 previously untreated patients, ORR was $85 \%$, and $90 \%$ of the responses were ongoing at 6 months. The intracranial response was $91 \%$ (95\% CI $59 \%$ to $100 \%)$. The most common adverse events were hypertension $(14 \%)$ and an increase in LFTs (12\%) [70]. Updated

Table 5 Current ongoing early phase I/II trials with MET inhibitors

\begin{tabular}{|c|c|c|c|c|}
\hline \multicolumn{5}{|l|}{ MET Inhibitor } \\
\hline Drug name & Mechanism of action & Clinical trial (phase) & Study design & Disease \\
\hline Bozitnib (APL-101) & c-MET receptor (HGFR) Inhibitor & NCT03175224 (1/2) & Monotherapy & $\begin{array}{l}\text { c-MET altered solid tumors includ- } \\
\text { ing NSCLC }\end{array}$ \\
\hline Capmatinib (INC280) & $\begin{array}{l}\text { MET Inhibition through HGFR } \\
\text { binding }\end{array}$ & NCT04139317 (2) & $\begin{array}{l}\text { Combination with Pembroli- } \\
\text { zumab }\end{array}$ & $\begin{array}{l}\text { EGFR wild type and ALK negative } \\
\text { NSCLC with high PDL1 expres- } \\
\text { sion }\end{array}$ \\
\hline Capmatinib (INC280) & $\begin{array}{l}\text { MET Inhibition through HGFR } \\
\text { binding }\end{array}$ & NCT02414139(2) & Monotherapy & $\begin{array}{l}\text { EGFR wild type and ALK negative } \\
\text { NSCLC with CMET alteration }\end{array}$ \\
\hline Glumetinib & $\begin{array}{l}\text { Small molecule MET kinase } \\
\text { Inhibitor }\end{array}$ & NCT04338243 (1/2) & Monotherapy & $\begin{array}{l}\text { T790M Mutation negative and Met } \\
\text { amplified NSCLC }\end{array}$ \\
\hline REGN5093 & $\begin{array}{l}\text { Bispecific antibody that Inhibits } \\
\text { MET }\end{array}$ & NCT04077099 (1/2) & Monotherapy & MET altered NSCLC \\
\hline Tepotinib & Selective MET inhibitor & NCT03940703 (2) & Combination with Osimertinib & $\begin{array}{l}\text { MET amplified NSCLC with EGFR } \\
\text { mutation }\end{array}$ \\
\hline TFX-0022 & MET, CSF1R, SRC kinase Inhibitor & NCT03993873 (1) & Monotherapy & NSCLC with MET alterations \\
\hline
\end{tabular}


overall efficacy and safety data continues to show that selpercatinib has durable antitumor activity in pts with RET-fusion + NSCLC [71]. A global, randomized, phase 3 trial NCT04194944 (LIBRETTO-431) evaluating selpercatinib compared with standard frontline therapy is ongoing.

Pralsetinib was approved by FDA based on the phase I/II ARROW trial, which showed efficacy in patients with RET fusion-positive NSCLC with or without prior therapy [72]. Updated results from the ARROW trial show an ORR of $62 \%$ with a DCR of $91 \%$ in patients with prior platinum therapy $(n=126)$ and $79 \%(n=68)$ with DCR of $93 \%$ in treatment naïve patients. The median PFS is 16.5 months in prior platinum group while it has still not matured in the treatment naïve group [73]. The most common TRAEs were increased aspartate aminotransferase (39\%), anemia (35\%), increased alanine aminotransferase (27\%), constipation (26\%) and hypertension (25\%). Overall, 6\% of patients discontinued treatment due to TRAEs [73]. A phase III clinical trial is currently enrolling patients (NCT04222972).

TPX-0046 is a next-generation RET inhibitor active in drug-resistant cancer models, including solvent front mutations (SFMs) mediated resistance [74]. A phase I/II clinical trial for RET inhibitor-resistant and naïve RETdriven cancers is ongoing (NCT04161391).

BOS172738 is an oral, highly potent and selective RET inhibitor [75]. It has $>300$-fold selectivity against vascular endothelial growth factor receptor 2 [76]. In a phase 1 clinical trial NCT03780517 it is being studied in RET-altered advanced solid tumors including advanced
NSCLC. According to the results reported BOS172738 exhibited a favorable safety profile in the studied 67 patients. The most common TEAEs were creatinine phosphokinase (CPK) increase (54\%), dyspnea (34\%), facial edema, aspartate aminotransferase elevation, anemia (25\% each) and neutropenia, diarrhea (22\% each). BOS172738 demonstrated broad anti-tumor activity with an investigator-assessed ORR of $33 \%(n=18 / 54)$ and a NSCLC ORR of 33\% $(n=10 / 30)$ [76]. Table 6 summarizes the ongoing phase I/II clinical trials involving RET inhibitors in patients with advanced NSCLC.

\section{BRAF/MEK inhibitors}

BRAF is a serine/threonine kinase involving the canonical MAP/ERK signaling pathway. Dabrafenib inhibits BRAF V600E mutations, and trametinib inhibits MEK [77]. Combination of dabrafenib and trametinib is now the preferred, and the only FDA approved first-line therapy based on a phase II trial that assessed this combination in 36 patients with newly diagnosed, metastatic NSCLC and BRAF V600E mutation [78].

LXH254 is a BRAF and CRAF inhibitor with activity in MAPK-driven tumor models. Oral LXH254 was well tolerated, with antitumor activity observed in a phase I trial of 75 patients with advanced pretreated solid tumors with MAPK pathway alterations [79]. It is currently being studied in a phase IB study in combination with LTT462 (ERK1/2 inhibitor), trametinib (MEK inhibitor), and ribociclib (CDK4/6 inhibitor) in patients with advanced KRAS or BRAF Mutant NSCLC (NCT02974725).

Table 6 Current ongoing early phase I/II trials with RET inhibitors

RET Inhibitors

\begin{tabular}{lllll}
\hline Drug name & Mechanism of action & Clinical trial (phase) & Study design & Disease \\
\hline Pralsetinib (BLU-667) & RET inhibitor & NCT03037385 (1/2) & Monotherapy & RET altered solid tumors including NSCLC \\
Selpercatinib (Loxo-292) & RET, VEGFR1, VEGFR3 Inhibitor & NCT03157128 (1/2) & Monotherapy & RET altered solid tumors including NSCLC \\
TPX-0046 & RET/SRC Inhibitor & NCT04161391 (1/2) & Monotherapy & RET altered solid tumors including NSCLC \\
BOS172738 & RET inhibitor & NCT03780517 (1) & Monotherapy & RET altered solid tumors including NSCLC
\end{tabular}

Table 7 Current ongoing early phase I/II trials with BRAF/MEK inhibitors BRAF/MEK inhibitors

\begin{tabular}{|c|c|c|c|c|}
\hline Drug name & Mechanism of action & Clinical trial (phase) & Study design & Disease \\
\hline ABM-1310 & BRAF inhibitor (BRAF V600E) & NCT04190628 (1) & Monotherapy & $\begin{array}{l}\text { Advanced BRAFV600 E mutated solid tumor } \\
\text { including NSCLC }\end{array}$ \\
\hline LXH254 & BRAF and CRAF inhibitor & NCT02974725 (1) & $\begin{array}{l}\text { Combination with LTT462, } \\
\text { Trametinib, Ribociclib }\end{array}$ & Advanced BRAF or KRAS mutant NSCLC \\
\hline Trametinib & MEK inhibitor & NCT03225664 (1/2) & Combination with Pembrolizumab & $\begin{array}{l}\text { Advanced NSCLC with EGFR or ALK mutation } \\
\text { with progression on first line therapy }\end{array}$ \\
\hline
\end{tabular}


ABM-1310 is an investigational, oral, small-molecule BRAF inhibitor undergoing study in phase I, first-inhuman, open-label study in patients with advanced solid cancer, including NSCLC with BRAF V600E mutation (NCT04190628). Table 7 summarizes the ongoing phase I/II clinical trials involving BRAF/MEK inhibitors in patients with advanced NSCLC.

\section{ROS1 inhibitors}

ROS1 is a distinct receptor tyrosine kinase like ALK. It is estimated to be present in $1-2 \%$ of patients with NSCLC (80). Crizotinib, entrectinib, and certinib are recommended first-line therapy options for these patients, according to the NCCN.

Entrectinib is an oral TKI that inhibits both ROS1 and TRK. Pooled data from 3 trials in 53 patients with-ROS1 positive metastatic NSCLC receiving entrectinib in the first-line showed an ORR of 77\% (41/53; 95\% CI 64-88\%). Intracranial ORR was 55\% (95\% CI 32-77\%). In the larger ROS1 population of 134 patients, Grade 3 and 4 adverse effects were seen in $34 \%$ of patients (81).

Lorlatinib is a third-generation TKI that targets ALK and ROS1. In a phase I-II trial with 69 patients with advanced ROS1 positive NSCLC after an estimated median duration of follow up of 21.1 months, 13 of 21 (62\%; 95\% CI 38-82\%) TKI naïve patients and 14 of 40 $(35 \% ; 21-52 \%)$ patients previously treated with crizotinib had an objective response. The intracranial responses were achieved in 7 of 11 TKI naive patients and 12 of 24 previous crizotinib treated patients. The most common adverse effects were hypertriglyceridemia (19\%) and hypercholesterolemia (14\%). No responses were seen in patients with G2032R mutations [82].

Repotrectinib is a next-generation ROS1/TRK inhibitor with $>90$-fold potency against ROS1 than crizotinib. Preclinical studies have shown inhibitory activity against ROS1 resistance mutations, including SFM G2032R. In a phase 1 study, repotrectinib was well tolerated and showed a 91\% overall response in TKI naïve ROS1 + NSCLC patients. $100 \%$ intracranial-ORR was observed in TKI naïve, and 75\% was observed in patients with one prior TKI [83]. A global phase 2 expansion study is actively enrolling (TRIDENT-1) (NCT03093116).

Taletrectinib (AB-10) is a potent and selective ROS/ NTRK inhibitor. In two phase I trials, NSCLC patients with ROS1 fusion who received taletrectinib as first line ROS1 TKI had an objective response rate (ORR) of $66.7 \%$ (6/9) and median progression-free survival (PFS) of 29.1 months [84]. Data from an ongoing phase II TRUST study (NCT04395677) of taletrectinib in Chinese NSCLC with ROS 1 fusion was presented. 22 pts had received taletrectinib treatment. Most pts $(54.5 \%, 12 / 22)$ had prior systematic chemotherapy; $31.8 \%(7 / 22)$ of pts had prior crizotinib treatment. ORR by investigator among the crizotinib naïve pts with tumor assessment $(N=11)$ was $100 \%$; $81.8 \%$ (18/22) of pts had TEAEs. $13.6 \%$ (3/22) were grade $\geq 3$, including fatigue, white blood cell decrease and transaminase elevation [85]. Table 8 summarizes the ongoing phase I/II clinical trials involving ROS1 inhibitors in patients with advanced NSCLC.

\section{NTRK gene fusion inhibitors}

TRK gene fusions act as oncogenic drivers for solid tumors, including lung cancer. NTRK fusions are oncogenic driver mutations in $0.1 \%$ of patients with NSCLC [86]. Larotrectinib and entrectinib are FDA-approved therapies in the first or subsequent line for patients with NTRK gene fusions.

Larotrectinib is a TRK fusion inhibitor. In a pooled analysis, $75 \%$ of the patients with NSCLC (9/12) patients showed ORR [87]. A phase II basket trial for solid tumors with NTRK fusion, including NSCLC, is enrolling patients (NCT02576431).

Entrectinib has also been assessed in patients with NTRK gene fusion-positive NSCLC in phase 1 and 2 trials. Pooled data from three trials with ten patients showed an ORR of 70\% (95\% CI 35-93\%; 7/10), with most patients $(70 \%)$ receiving one or more prior lines of therapy [88]. A phase 2 study of patients with solid tumors,

Table 8 Current ongoing early phase I/II trials with ROS1 inhibitors

\begin{tabular}{|c|c|c|c|c|}
\hline \multicolumn{5}{|c|}{ ROS1 inhibitors } \\
\hline Drug name & Mechanism of action & Clinical trial (phase) & Study design & Disease \\
\hline Ceritinib & ALK and ROS1 inhibitor & NCT03399487 (2) & Monotherapy & ROS 1 rearranged NSCLC \\
\hline Crizotinib & ALK, HGFR, C-Met and RON Inhibitor & NCT04084717 (2) & Monotherapy & $\begin{array}{l}\text { NSCLC with ROS1 rearrangement or MET } \\
\text { activating mutation/amplification }\end{array}$ \\
\hline Repotrectinib & ROS1/TRK inhibitor & NCT03093116 (2) & Monotherapy & ROS1/TRK altered NSCLC \\
\hline Lorlatinib & ALK and ROS1 inhibitor & NCT02927340 (2) & Monotherapy & ALK/ROS1 rearranged NSCLC with CNS disease \\
\hline Taletrectinib & ROS 1 and TRK fusion inhibitor & NCT04395677 (2) & Monotherapy & Advanced NSCLC with ROS1 fusion gene \\
\hline
\end{tabular}


including NSCLC with NTRK and ROS1 gene alteration, is currently enrolling patients (NCT02568267).

A phase II expansion study (TRIDENT-1) testing repotrectinib is also enrolling patients with TRK gene rearrangement (NCT03093116).

NTRK1 gene encodes tropomysin receptor kinase A (TrKA) protein. Upregulation of TrKA can be caused either by NTRK1 gene fusion or intact TrKA protein overexpression causing oncogenesis in multiple tumors including NSCLC. VMD-928 is the first oral smallmolecule TrkA (NTRK1) selective inhibitor. In the first in-human phase 1 trial (NCT03556228) 20 patients were accrued to 4 dose escalation cohorts ranging from $300 \mathrm{mg} /$ day to $2400 \mathrm{mg} /$ day. Common adverse events related to therapy were dark stool (35\%), elevated liver enzymes (25\%, primarily at $2400 \mathrm{mg}$ /day), fatigue, nausea or vomiting, and decreased appetite (20\% each). Tumor types with reported high TrkA protein expression including squamous cell carcinoma of the lung (71\%) are being accrued [89]. Table 9 summarizes the ongoing phase I/II clinical trials involving NTRK inhibitors in patients with advanced NSCLC.

\section{KRAS inhibitors}

KRAS (Kirsten RAT Sarcoma Viral Oncogene Homologue) is the most frequently mutated oncogene in human cancers and encodes guanosine triphosphatase and regulates signal transduction [90]. KRAS mutation is often associated with resistance to targeted therapies and poor outcomes in patients [91]. The KRAS p.G12C mutation occurs in about $13 \%$ of NSCLC [92].

Sotorasib (AMG510) is a small molecule that inhibits KARS G12C through interaction with the P2 pocket. In a single-group, phase 2 trial, sotorasib was administered orally at a dose of $960 \mathrm{mg}$ once daily, in patients with KRAS p.G12C-mutated advanced NSCLC previously treated with standard therapies. Among the 126 enrolled patients, the majority $(81.0 \%)$ had previously received both platinum-based chemotherapy and inhibitors of programmed death 1 (PD-1) or programmed death ligand 1 (PD-L1). An objective response was observed in 46 patients $(37.1 \%)$ including $4(3.2 \%)$ who had a complete response. The median DOR was 11.1 months with DCR of $80.6 \%$. The median PFS was 6.8 months and the median OS was 12.5 months. TRAEs occurred in 88 of 126 patients (69.8\%), including grade 3 events in 25 patients $(19.8 \%)$ and a grade 4 event in $1(0.8 \%)$. The most frequent TRAEs were diarrhea (31.7\%), nausea (19.0\%), increase in the alanine aminotransferase level (15.1\%), increase in the aspartate aminotransferase level (15.1\%), and fatigue $(11.1 \%)$ [93]. In the exploratory analyses of the phase 2 CodeBreak 100 trial, the clinical benefit of sotorasib was observed across patient subgroups including patients with STK11 and KEAP1 mutations (94). Sotorasib was approved by FDA for KRASG12C mutated NSCLC in May 2021 [95]. A global phase III randomized study comparing sotorasib to docetaxel in KRAS G12C mutant NSCLC (CodeBreak 200) has begun recruiting (NCT04303780).

Adagrasib (MRTX-849) is a small-molecule inhibitor of KRAS G12C that binds to cysteine 12 in the inducible switch II pocket of KRAS G12C, inactivating it and preventing oncogenic signaling. It is currently being evaluated in a phase I/II study [96]. In the updated results of Krystal-1 trial (NCT03785249), 79 patients with pretreated NSCLC were treated with Adagrasib $600 \mathrm{mg}$ bid. The only grade $3 / 4$ treatment-related serious adverse event was hyponatremia $(3 \%, 2 / 79)$. Among the 51 patients evaluable for clinical activity (14 from Phase 1/1b; 37 from Phase 2), $45 \%$ of patients had an objective response. The disease control rate was 96\% (49/51) [97]. In KRYSTAL-12 (NCT04685135) adagrasib versus docetaxel are being studied in a phase III trial in patients with previously treated NSCLC with KRAS G12C mutation. The study is designed to demonstrate improvement in the dual primary endpoints of progression-free survival (PFS) and overall survival (OS) [98].

Other KRAS inhibitors that are currently being developed and studied in phase I/II trials include GDC-6036 (NCT04449874), D-1553 (NCT04585035), and Rigosertib (NCT04263090). Table 10 summarizes the ongoing phase I/II clinical trials involving KRAS inhibitors in patients with advanced NSCLC.

Table 9 Current ongoing early phase I/II trials with NTRK fusion inhibitors

\begin{tabular}{|c|c|c|c|c|}
\hline \multicolumn{5}{|c|}{ NTRK gene fusion inhibitors } \\
\hline \multicolumn{5}{|c|}{$\begin{array}{l}\text { NTRK gene fusion inhibitors } \\
\text { Drug name Mechanism of action }\end{array}$} \\
\hline \multirow{2}{*}{$\begin{array}{l}\text { Larotrectinib } \\
\text { Repotrectinib }\end{array}$} & \multirow{2}{*}{$\begin{array}{l}\text { TRK fusion inhibitor } \\
\text { TRK, ROS 1, ALK fusion inhibitor }\end{array}$} & NCT02576431 (2) & Monotherapy & Solid tumors including NSCLC with NTRK fusions \\
\hline & & NCT03093116 (1) & Monotherapy & $\begin{array}{l}\text { Solid tumor including NSLC with ALK, ROS1, NTRK1/2/3 } \\
\text { gene rearrangement }\end{array}$ \\
\hline Entrectinib & ROS1 and TRK fusion inhibitor & NCT02568267 (2) & Monotherapy & $\begin{array}{l}\text { Solid tumors including NSCLC with NTRK fusions and } \\
\text { ROS1 rearrangements }\end{array}$ \\
\hline VMD-928 & small-molecule TrkA (NTRK1) inhibitor & NCT03556228 (1) & Monotherapy & Advanced solid tumors and lymphoma including NSCLC \\
\hline
\end{tabular}


Table 10 Current ongoing early phase I/II trials with KRAS inhibitors

\begin{tabular}{|c|c|c|c|c|}
\hline \multicolumn{5}{|l|}{ KRAS inhibitors } \\
\hline Drug name & Mechanism of action & Clinical trial (phase) & Study design & Disease \\
\hline Adagrasib (MRTX849) & KRAS G12C Inhibitor & NCT04330664 (1/2) & Combination with TNO155 & $\begin{array}{l}\text { KRAS p.G12C mutant solid tumors } \\
\text { including NSCLC }\end{array}$ \\
\hline Adagrasib (MRTX849) & Irreversible KRAS G12C Inhibitor & NCT04613596 (1/2) & $\begin{array}{l}\text { Combination with Pembroli- } \\
\text { zumab }\end{array}$ & $\begin{array}{l}\text { KRAS p.G12C mutant NSCLC with } \\
\text { known PDL1 TPS score }\end{array}$ \\
\hline GDC-6036 & KRAS G12C Inhibitor & NCT04449874 (1) & Monotherapy & KRAS p.G12C mutant NSCLC \\
\hline D-1553 & KRAS G12C Inhibitor & NCT04585035 (1/2) & $\begin{array}{l}\text { Monotherapy and combination } \\
\text { with other standard therapies }\end{array}$ & KRAS p.G12C mutant NSCLC \\
\hline Rigosertib & RAS-mimetic & NCT04263090 (1/2) & Combination with Nivolumab & $\begin{array}{l}\text { KRAS mutant NSCLC with progres- } \\
\text { sion on fist line therapy }\end{array}$ \\
\hline Sotorasib (AMG 510) & KRAS G12C Inhibitor & NCT03600883 (1/2) & Monotherapy & KRAS p.G12C mutant NSCLC \\
\hline Sotorasib (AMG 510) & KRAS G12C Inhibitor & NCT04303780 (3) & Monotherapy & KRAS p.G12C mutant NSCLC \\
\hline
\end{tabular}

\section{Drug antibody conjugates}

Antibody-drug conjugates (ADCs) are cancer agents with a cytotoxic payload linked to a monoclonal antibody $(\mathrm{mAB})$ that targets cancer cells.

Patritumab deruxtecan (HER3-DXd/U3-1402) is a HER3-targeted ADC with a fully humanized antibody, novel cleavable peptide-based linker, and topoisomerase I inhibitor payload via a tetrapeptide-based cleavable linker. It has demonstrated tolerable safety and antitumor activity in an ongoing study (NCT03260491) [99]. Efficacy and safety of patritumab deruxtecan in heavily pretreated 57 metastatic NSCLC patients with progressive disease on EGFR TKI was presented in ASCO 2021. At a dose of $5.6 \mathrm{mg} / \mathrm{kg}$ IV Q3W with median follow-up of 10.2 months confirmed ORR was seen in $39 \%(22 / 57)$ with DCR of $72 \%$. Median DOR was 6.9 months, and median PFS was 8.2 mo. Antitumor activity was observed across diverse mechanisms of EGFR TKI resistance, including those not directly related to HER3 (EGFR C797S, MET or HER2 amp, and BRAF fusion). The most common grade $\geq 3$ adverse events (AEs) were thrombocytopenia (30\%), neutropenia (19\%), and fatigue (14\%). Drug-related interstitial lung disease occurred in 4 pts. $6 / 57$ pts (11\%) had AEs associated with treatment discontinuation [100].

Cofetuzumab pelidotin (ABBV-647) is an anti-PTK7 antibody-drug conjugate comprising the hu6MO24 monoclonal antibody, a cleavable cysteine-reactive linker, and Aur0101 (an auristatin microtubule inhibitor) [101]. Protein tyrosine kinase 7 (PTK7) is a highly conserved receptor tyrosine kinase involved in the Wnt signaling pathway and is overexpressed in multiple cancer types, including NSCLC [102]. A phase 1 trial previously showed promising antitumor activity and manageable safety in advance solid cancer including NSCLC. DCR of $56 \%$ was seen in 25 heavily pretreated NSCLC patients [103]. A phase 1b study (NCT04189614) is currently enrolling 40 recurrent NSCLC patients expressing PTK7 to study its safety and tolerability [101].

Carcinoembryonic antigen-related cell adhesion molecule 5 (CEACAM5) is a cell-surface glycoprotein highly expressed in NSCLC. SAR408701 is a DM4 conjugated ADC targeting CEACAM5. Updated safety and efficacy data for SAR408701 from the expansion part of the first-in-human study was reported in NSCLC patients. Two cohorts of patients including moderate (CEACAM5 expression at $\geq 2+$ intensity between $\geq 1 \%$ to $<50 \%)$ and high expression $(\geq 50 \%$ of the tumor cell population) were analyzed. ORR was $7.1 \%$ in the moderate expression group and $20.3 \%$ in the high expression cohort. Grade $\geq 3$ TEAEs were found in $47.8 \%$ of pts [104]. A phase 3 trial is underway (NCT04154956).

TROP2 is an intracellular calcium signaling transducer overexpressed in NSCLC, portending poor survival. DS-1062 (datopotamab deruxtecan) is an ADC consisting of a humanized anti-TROP2 IgG1 monoclonal antibody attached to a topoisomerase I inhibitor payload via a tetrapeptide-based cleavable linker [105]. Results from the ongoing phase 1 study (TROPION-PanTumor01; Spira, WCLC 2020) demonstrated an overall response rate (ORR) of $21 \%$, a disease control rate (DCR) of $67 \%$, and a preliminary median progression-free survival (PFS) of 8.2 months (all by BICR), with a manageable safety profile, in patients with NSCLC who were treated with $6 \mathrm{mg} / \mathrm{kg}$ of Dato-DXd. The most common TEAEs were reported in 128 patients (96\%); most frequent TEAEs $(\geq 30 \%)$ included nausea (50\%), stomatitis $(44 \%)$, alopecia (40\%), and fatigue (33\%). Sixty-four patients (48\%) experienced grade $\geq 3$ TEAEs (most frequently dyspnea [5\%]). There were 12 patients (9\%) with interstitial lung disease [105]. A randomized, phase 3 study of DS-1062 versus 
Table 11 Current ongoing early phase I/II trials with ADC

\begin{tabular}{|c|c|c|c|c|}
\hline \multicolumn{5}{|l|}{$\overline{A D C}$} \\
\hline Drug name & Mechanism of action & Clinical trial (phase) & Study design & Disease \\
\hline CAB-ROR2-ADC & Anti-ROR2 ADC & NCT03504488 (1/2) & Monotherapy & $\begin{array}{l}\text { Advanced solid tumors includ- } \\
\text { ing NSCLC }\end{array}$ \\
\hline Cofetuzumab Pelidotin & PTK7 ADC & NCT04189614 (1b) & Monotherapy & $\begin{array}{l}\text { PTK7-expressing recurrent } \\
\text { NSCLC }\end{array}$ \\
\hline DS-1062a & ADC targeting TROP2 & NCT04612751 (1) & Combination with Durvalumab & $\begin{array}{l}\text { Advanced NSCLC with progres- } \\
\text { sion on chemotherapy and } \\
\text { immunotherapy }\end{array}$ \\
\hline MGC018 & ADC delivers Duocarmycin & NCT03729596 (1/2) & $\begin{array}{l}\text { Monotherapy and combina- } \\
\text { tion with MGA012 (anti-PD1 }\end{array}$ & $\begin{array}{l}\text { Advanced solid tumors includ- } \\
\text { ing NSCLC }\end{array}$ \\
\hline $\begin{array}{l}\text { U3-1402 (Patritumab derux- } \\
\text { tecan) }\end{array}$ & $\begin{array}{l}\text { Drug (MAAA-1181a) linked } \\
\text { to AB (Patritumab) }\end{array}$ & NCT03260491 (1) & Monotherapy & $\begin{array}{l}\text { Advanced NSCLC with acquired } \\
\text { resistance to EGFR TKI }\end{array}$ \\
\hline
\end{tabular}

Table 12 Current ongoing early phase I/II trials with mTOR/PI3K inhibitors

\begin{tabular}{|c|c|c|c|c|}
\hline \multicolumn{5}{|c|}{ mTOR/PI3K pathway Inhibitors } \\
\hline \multicolumn{5}{|c|}{$\begin{array}{l}\text { mIOR/PISK pathway InhIbitors } \\
\text { Drug name Mechanism of action }\end{array}$} \\
\hline Gedatolisib (PF-05212384) & pan-PI3K/mTOR inhibitor & NCT03065062 (1) & Combination with Palbociclib & $\begin{array}{l}\text { Advanced tumors including } \\
\text { squamous NSCLC }\end{array}$ \\
\hline Idelalisib & PI3K inhibitor & NCT03257722 (1) & $\begin{array}{l}\text { Combination with Pembroli- } \\
\text { zumab }\end{array}$ & $\begin{array}{l}\text { Advanced NSCLC with progres- } \\
\text { sion on first line therapy }\end{array}$ \\
\hline Nab Rapamycin (ABI-009) & mTOR inhibitor & NCT03190174 (1/2) & Combination with Nivolumab & $\begin{array}{l}\text { Advanced solid tumors includ- } \\
\text { ing NSCLC }\end{array}$ \\
\hline RMC-5552 & $\begin{array}{l}\text { bi-steric mTORC1-selective } \\
\text { inhibitor }\end{array}$ & NCT04774952 (1/1b) & Monotherapy & $\begin{array}{l}\text { Advanced solid tumors includ- } \\
\text { ing NSCLC }\end{array}$ \\
\hline Sapanisertib & mTORC1/mTORC2 inhibitor & NCT02417701 (2) & Monotherapy & $\begin{array}{l}\text { KRAS mutant NSCLC with KEAP1 } \\
\text { mutation }\end{array}$ \\
\hline Sirolimus & mTOR inhibitor & NCT01737502 (1/2) & Combination with Auranofin & $\begin{array}{l}\text { Advanced or Recurrent Lung } \\
\text { Cancer }\end{array}$ \\
\hline
\end{tabular}

docetaxel in previously treated advanced or metastatic non-small cell lung cancer (NSCLC) without actionable genomic alterations (TROPION-Lung01) is currently also underway (NCT04656652) [106].

MGC018 is an investigational ADC with a Duocarmycin payload linked to an anti-B7-H3 mAB. It is hypothesized that MGC018 has activity against B7-H3 expressing tumors (NCT03729596) [107]. Table 11 summarizes the ongoing phase I/II clinical trials involving ADC in patients with advanced NSCLC.

\section{PI3K/AKT/mTORC inhibitors}

The PI3K/AKT/mTOR pathway has been heavily implicated in both tumorigenesis and progression of disease in NSCLC. In a study, 1144 patients with NSCLC underwent next generation sequencing for PI3KCA mutations. Mutations were identified in $3.7 \%$ of the patients [108]. Non-small cell lung squamous cell carcinoma (8.9\%) were more likely to be have these mutations when compared with adenocarcinoma (2.9\%). On the other hand upregulation of mTOR pathway is seen in up to $90 \%$ of the patients with NSCLC adenocarcinoma compared to $40 \%$ of the patients with squamous cell carcinoma [109]. S6K and 4E-BP1 are the downstream products of mTOR activation. These have also been identified in up to $58 \%$ and $25 \%$ of NSCLC specimens respectively [110]. It is also postulated that in patients with an EGFR mutant NSCLC, the AKT/mTOR pathway is constitutively activated in $67 \%$ of cases [111].

Sapanisertib (TAK228) is an oral TORC1/2 inhibitor. In a phase II trial with stage IV squamous NSCLC patients, it showed differential activity in NFE2L2 (ORR of 20\%) and KEAP1(ORR of 17\%) mutant patients [112]. Most common AEs included hyperglycemia (72\%), fatigue (32\%), diarrhea (32\%), decreased appetite (32\%).

Sirolimus binds to FKBP-12, an intracellular protein, to form an immunosuppressive complex which inhibits mTOR [113]. It is being studied in a phase I/II trial NCT01737502 with auranofin (gold salt) in advanced or recurrent NSCLC patients without standard treatment 
Table 13 Current ongoing early phase I/II trials with miscellaneous target inhibitors

\begin{tabular}{|c|c|c|c|c|}
\hline Drug name & Mechanism of action & Clinical trial (phase) & Study design & Disease \\
\hline \multicolumn{5}{|l|}{ ERBB2(HER2) inhibitors } \\
\hline Ado-trastuzumab emtansine & $\begin{array}{l}\text { HER2-targeted antibody-drug } \\
\text { conjugate }\end{array}$ & NCT03784599 (1/2) & Combination with osimertinib & EGFR mutant advanced NSCLC \\
\hline Mobocertinib (TAk-788) & $\begin{array}{l}\text { TKI targeting EGFR ex20ins } \\
\text { mutations }\end{array}$ & NCT02716116 (1/2) & $\begin{array}{l}\text { Combination with chemo- } \\
\text { therapy }\end{array}$ & $\begin{array}{l}\text { EGFR and HER2 exon } 20 \text { inser- } \\
\text { tion in advanced NSCLC }\end{array}$ \\
\hline Poziotinib & $\begin{array}{l}\text { EGFR, HER2 and HER } 4 \text { inhibi- } \\
\text { tors }\end{array}$ & NCT03066206 (2) & Monotherapy & $\begin{array}{l}\text { EGFR exon } 20 \text { and HER2 exon } 20 \\
\text { mutated advanced NSCLC }\end{array}$ \\
\hline trastuzumab deruxtecan & $\begin{array}{l}\text { HER2-directed antibody-drug } \\
\text { conjugate }\end{array}$ & NCT04644237 (2) & Monotherapy & HER2 mutated advanced NSCLC \\
\hline \multicolumn{5}{|l|}{ SHP2 inhibitors } \\
\hline JAB-3068 & SHP2 inhibitor & NCT03518554 (1) & Monotherapy & $\begin{array}{l}\text { Advanced solid tumors includ- } \\
\text { ing NSCLC }\end{array}$ \\
\hline TNO155 & SHP2 inhibitor & NCT03114319 (1) & $\begin{array}{l}\text { Monotherapy and combina- } \\
\text { tion with Nazartinib }\end{array}$ & $\begin{array}{l}\text { Advanced solid tumors includ- } \\
\text { ing NSCLC }\end{array}$ \\
\hline \multicolumn{5}{|c|}{ Other miscellaneous target inhibitors } \\
\hline Aliseritib & $\begin{array}{l}\text { Selective aurora A kinase } \\
\text { inhibitor }\end{array}$ & NCT04085315 (1/2) & Combination with Osimertinib & $\begin{array}{l}\text { EGFR mutant NSCLC progress- } \\
\text { ing after first line TKI }\end{array}$ \\
\hline Anlotinib & $\begin{array}{l}\text { VEGFR, FGFR, PDGFR, c-kit } \\
\text { Inhibitor }\end{array}$ & NCT04165330 (1/2) & Combination with Nivolumab & Solid tumors including NSCLC \\
\hline Apatinib & VEGFR-2 Inhibitor & NCT03811054 (2) & Combination with EGFR-TKI & $\begin{array}{l}\text { EGFR mutant NSCLC progress- } \\
\text { ing after first line TKI }\end{array}$ \\
\hline APG-1252 & $\begin{array}{l}\text { Small molecule inhibitor of } \\
\text { BCL2 }\end{array}$ & NCT04001777 (1) & $\begin{array}{l}\text { Monotherapy and combina- } \\
\text { tion with Osimertinib }\end{array}$ & EGFR mutant NSCLC \\
\hline BMS-986205 & IDO1 inhibitor & NCT02658890 (1/2) & $\begin{array}{l}\text { Combination with Nivolumab } \\
\text { and Ipilimumab }\end{array}$ & $\begin{array}{l}\text { Advanced solid tumors includ- } \\
\text { ing NSCLC }\end{array}$ \\
\hline Eprenetapopt (Apr-246) & $\begin{array}{l}\text { Stabilizes p53 in normal, } \\
\text { functional structure }\end{array}$ & NCT04383938 (1/2) & $\begin{array}{l}\text { Combination with Pembroli- } \\
\text { zumab }\end{array}$ & $\begin{array}{l}\text { Advanced solid tumors includ- } \\
\text { ing NSCLC }\end{array}$ \\
\hline HBI-8000 & Histone deacetylase inhibitor & NCT02718066 (1/2) & Combination with Nivolumab & Advanced NSCLC \\
\hline Idelalisib & PI3K inhibitor & NCT03257722 (1/2) & $\begin{array}{l}\text { Combination with Pembroli- } \\
\text { zumab }\end{array}$ & $\begin{array}{l}\text { Advanced NSCLC with progres- } \\
\text { sion on first line therapy }\end{array}$ \\
\hline IRX4204 & $\begin{array}{l}\text { Rexinoid, potent activator of } \\
\text { RXRs }\end{array}$ & NCT02991651 (1) & $\begin{array}{l}\text { Monotherapy and combina- } \\
\text { tion with Erlotinib }\end{array}$ & $\begin{array}{l}\text { Advanced NSCLC with progres- } \\
\text { sion on two lines of therapy }\end{array}$ \\
\hline NC318 & $\lg G 1$ mAB specific for S15 & NCT03665285 (1/2) & Monotherapy & $\begin{array}{l}\text { Advanced solid tumors includ- } \\
\text { ing NSCLC }\end{array}$ \\
\hline Ningetinib (CT053PTSA) & $\begin{array}{l}\text { Multi kinase inhibitor MET/ } \\
\text { HGFR }\end{array}$ & NCT03758287 (1/2) & Combination with Gefitinib & $\begin{array}{l}\text { NSCLC with EGFR mutation and } \\
\text { T790M negative }\end{array}$ \\
\hline Nintedanib & PDGFR, FGFR, VEGFR inhibitor & NCT03377023 (1/2) & $\begin{array}{l}\text { Combination with Nivolumab } \\
\text { and Ipilimumab }\end{array}$ & Advanced or metastatic NSCLC \\
\hline RGX-104 & Liver $X$ receptor agonist & NCT02922764 (1) & $\begin{array}{l}\text { Monotherapy or in combina- } \\
\text { tion with immunotherapy or } \\
\text { chemotherapy }\end{array}$ & $\begin{array}{l}\text { Advanced solid tumors includ- } \\
\text { ing NSCLC }\end{array}$ \\
\hline Rucaparib & PARP inhibitor & NCT03845296 (2) & Monotherapy & Recurrent NSCLC \\
\hline Selinexor & Exportin 1 inhibitor & NCT03095612 (1/2) & Combination with docetaxel & $\begin{array}{l}\text { Advanced KRAS mutant NSCLC } \\
\text { with progression on first line } \\
\text { therapy }\end{array}$ \\
\hline Selumetinib & MAPK inhibitor & NCT03392246 (2) & Combination with Osimertinib & Advanced EGFR mutant NSCLC \\
\hline Ramucirumab & VEGFR2 antagonist & NCT03909334 (2) & Combination with Osimertinib & EGFR mutant NSCLC \\
\hline Telaglenastat $\mathrm{HCL}$ & Glutaminase inhibitor & NCT03831932 (1/2) & Combination with Osimertinib & Advanced EGFR mutant NSCLC \\
\hline Varlilumab & Anti CD27 antibody & NCT04081688 (1) & $\begin{array}{l}\text { Combination with Atezoli- } \\
\text { zumab }\end{array}$ & $\begin{array}{l}\text { Advanced NSCLC with progres- } \\
\text { sion on first line therapy }\end{array}$ \\
\hline Vorolanib & VEGFR/PDGFR inhibitor & NCT03583086 (1/2) & Combination with Nivolumab & Solid tumors including NSCLC \\
\hline $\mathrm{ZN}-\mathrm{c3}$ & WEE1 inhibitor & NCT04158336 (1/2) & $\begin{array}{l}\text { Combination with Talazoparib } \\
\text { or Pembrolizumab }\end{array}$ & $\begin{array}{l}\text { Advanced solid tumors includ- } \\
\text { ing NSCLC }\end{array}$ \\
\hline RBN-2397 & PARP7 inhibitor & NCT04053673 (1) & Monotherapy & $\begin{array}{l}\text { Advanced solid tumors includ- } \\
\text { ing NSCLC }\end{array}$ \\
\hline
\end{tabular}


options. Primary outcomes include maximal tolerated dose of auranofin, number and severity of adverse events and progression free survival.

Gedatolisib (PF-05212384) is an intravenous, ATPcompetitive, pan-PI3K/mTORi that has demonstrated significant antitumor activity in preclinical models. A first in-human study (NCT00940498) evaluated the safety, tolerability, PK, PD, and preliminary activity of gedatolisib in 78 patients with advanced solid tumors [114]. This study demonstrated manageable safety, with stomatitis and nausea as the most frequent AEs. There were two PRs in this heavily pretreated patient population. A phase I clinical trial (NCT03065062) of PI3K/ mTOR inhibitor Gedatolisib in combination with CDK4/6 inhibitor Palbociclib is currently recruiting patients with advanced solid cancer patients including squamous NSCLC.

RMC-5552 is a bi-steric mTORC1-selective inhibitor [115]. It is currently being evaluated in a phase $\mathrm{I} / \mathrm{Ib}$, open label, multicenter, dose escalation trial (NCT04774952) as monotherapy in adults with relapsed refractory solid tumor including NSCLC.

Nab-Rapamycin (ABI-009), an mTOR inhibitor, is under investigation in a phase I/II trial with Nivolumab in patients with advanced solid tumors, including NSCLC (NCT03190174).

In combination with Pembrolizumab, Idelalisib, a PI3K inhibitor, is being looked at in patients with advanced NSCLC with progression on first-line therapy (NCT03257722). Table 12 summarizes the ongoing phase I/II clinical trials involving mTOR/P13K inhibitors in patients with advanced NSCLC.

\section{Miscellaneous target inhibitors}

ERBB2 inhibitors Human epidermal growth factor receptor 2 (HER2, ERBB2) activating mutations occur in $2 \%$ of lung cancers (116). Ado-trastuzumab emtansine (T-DM1) is a HER2 targeted antibody-drug conjugate. NCCN recommends T-DM1 as an option for patients with ERBB2 mutated NSCLC patients based on a phase II basket trial [117].

Trastuzumab deruxtecan (T-DXd; DS-8201) is currently being evaluated in DESTINY-Lung01 trial (NCT03505710). Interim results presented in ASCO 2020 showed an ORR of $61.9 \%$ (95\% CI 45.6-76.4\%) with a DCR of $90.5 \%$ (95\% CI 77.4-97.3\%) in pretreated population; estimated median PFS was 14.0 month (95\% CI 6.4-14.0 month). TRAE caused drug discontinuation in 10 patients (23.8\%). HER2 mutations were predominantly in the kinase domain (90.5\%) [118].

Combination of trastuzumab, pertuzumab and docetaxel was studied in as phase II IFCT-1703 R2D2 trial which enrolled patients with advanced NSCLC harboring
HER2 mutation after progression of disease on $\geq 1$ platinum based chemotherapy. In the 44 evaluable patients, ORR was $29 \%(n=13)$ and stable disease was seen in $56 \%(n=26)$ of the patients. Median PFS was 6.8 months. Median duration of treatment in patients with confirmed response $(n=13)$ was 10 months. Grade $3 / 4$ treatmentrelated adverse events (AEs) were observed in $64 \%$ of patients. Most frequent grade $\geq 3$ AEs were neutropenia (33\%), diarrhea (13\%) and anemia (9\%). Grade 1/2 dyspnea was observed in 3 (6.7\%) patients [119].

SHP2 inhibitors SHP2 is a non-receptor protein tyrosine phosphatase encoded by the PTPN11 gene and is involved in cell growth differentiation via the MAPK signaling pathway [120].

TNO155 is a highly potent first-in-class SHP2 inhibitor [121]. A phase 1 dose-finding study of TNO155, with advanced solid tumors including EGFR or KRAS G12 mutant NSCLC, is currently recruiting patients (NCT03114319).

JAB-3068 is an oral SHP2 inhibitor being studied in a first-in-human study in patients with advanced solid tumors including NSCLC, in a phase I/II clinical trial (NCT03565003).

Others Aliseritib is a selective aurora A kinase inhibitor currently under investigation in a phase I/II trial NCT04085315 with osimertinib in patients with EGFR mutant NSCLC progressing after first-line therapy. APG1252 is a small molecule BCL2 inhibitor undergoing phase 1 trial NCT04001777 as monotherapy or in combination with osimertinib. APR0246 (Eprenetapopt) stabilizes p53 in normal functional structure and is being evaluated in advanced solid tumors, including NSCLC combined with Pembrolizumab in a phase I/II trial NCT04383938. A first inhuman phase 1 study of novel PARP7 inhibitor RBN2397 in patients with advanced solid cancers including NSCLC showed tolerability, dose dependent increases in plasma exposures, evidence of target inhibition, and preliminary signs of clinical activity [122]. Study expansion is planned to evaluate safety and efficacy in squamous NSCLC, HNSCC, HR + breast cancer, and PARP7 amplified tumors (NCT04053673). Table 13 summarizes the ongoing phase I/II clinical trials involving miscellaneous target inhibitors in patients with advanced NSCLC.

\section{Conclusion}

Lung cancer mortality has improved in the last decade largely due to the development of novel agents targeting actionable mutations in cancer cells. Although these drugs have revolutionized our clinical practice, resistance to these agents remains a reality. Identifying 
escape pathways and utilizing next-generation drugs by themselves or in combination can help us overcome this problem.

\author{
Abbreviations \\ NSCLC: Non-small cell lung cancer; EGFR: Endothelial growth factor receptor; \\ ALK: Anaplastic lymphoma kinase; PFS: Progression free survival; ORR: Overall \\ response rate; OS: Overall survival; TRAE: Treatment related adverse effects; \\ TEAE: Treatment emergent adverse effects.
}

\section{Acknowledgements}

None

\section{Authors' contributions}

$Y L$ and $U M$ designed the study. UM drafted the manuscript. $Y L, R M$, and $Y Z$ participated in the manuscript preparation and revisions. All authors read and approved the final manuscript.

\section{Funding}

This work was supported by the National Institutes of Health (Grant Number is K12CA090628, Y Lou).

\section{Availability of data and materials}

The material supporting the conclusion of this review has been included within the article.

\section{Declarations}

\section{Ethics approval and consent to participate}

This is not applicable to this review.

\section{Consent for publication}

This is not applicable to this review.

\section{Competing interests}

Yanyan Lou: Advisory board: AstraZeneca, Novocure, Janssen Pharmaceuticals. Consultant: AstraZeneca. Honorarium: Clarion health care. Research Funding Support: Merck, MacroGenics, Tolero Pharmaceuticals, AstraZeneca, Vaccinex, Blueprint Medicines, Harpoon Therapeutics, Sun Pharma Advanced Research, Bristol-Myers Squibb, Kyowa Pharmaceuticals, Tesaro, Bayer HealthCare. Rami Manochakian: Advisory Boards: Astra Zeneca, Guardant Health, Novocure, Takeda. Consulting: AstraZeneca. Yujie Zhao: Research Funding Support: Zai Lab, PDS Biotechnology, Transgen, Umair Majeed: None.

Received: 20 April 2021 Accepted: 29 June 2021

Published online: 08 July 2021

\section{References}

1. Siegel RL, Miller KD, Jemal A. Cancer statistics, 2020. CA Cancer J Clin. 2020;70(1):7-30

2. ACSCFFAACS. American Cancer Society. Cancer Facts \& Figures 2020. Atlanta: American Cancer Society; 2020.

3. Howlader NNA, Krapcho M, Miller D, Brest A, Yu M, Ruhl J, Tatalovich Z, Mariotto A, Lewis DR, Chen HS, Feuer EJ, Cronin KA (eds). SEER Cancer Statistics Review, 1975-2017, National Cancer Institute. Bethesda, MD, https://seer.cancer.gov/csr/1975_2017/, based on November 2019 SEER data submission, posted to the SEER web site, April 2020

4. Yuan $\mathrm{M}$, Huang $\mathrm{L}-\mathrm{L}$, Chen $\mathrm{J}-\mathrm{H}, \mathrm{Wu} J, \mathrm{X} u \mathrm{Q}$. The emerging treatment landscape of targeted therapy in non-small-cell lung cancer. Signal Transduct Target Ther. 2019;4(1):61

5. Howlader N, Forjaz G, Mooradian MJ, Meza R, Kong CY, Cronin KA, et al. The effect of advances in lung-cancer treatment on population mortality. N Engl J Med. 2020;383(7):640-9.

6. Lin JJ, Shaw AT. resisting resistance: targeted therapies in lung cancer. Trends Cancer. 2016;2(7):350-64.
7. Jordan EJ, Kim HR, Arcila ME, Barron D, Chakravarty D, Gao J, et al. Prospective comprehensive molecular characterization of lung adenocarcinomas for efficient patient matching to approved and emerging therapies. Cancer Discov. 2017;7(6):596-609.

8. NCCN. NSCLC clinical practice guidelines version 2.2021. 2020. https:// www.nccn.org/professionals/physician_gls/pdf/nscl_blocks.pdf.

9. AACR Project GENIE. Powering precision medicine through an international consortium. Cancer Discov. 2017;7(8):818-31.

10. Sholl LM, Aisner DL, Varella-Garcia M, Berry LD, Dias-Santagata D, Wistuba II, et al. Multi-institutional oncogenic driver mutation analysis in lung adenocarcinoma: the lung cancer mutation consortium experience. JThorac Oncol. 2015;10(5):768-77.

11. Shi Y, Au JS-K, Thongprasert S, Srinivasan S, Tsai C-M, Khoa MT, et al. A prospective, molecular epidemiology study of EGFR mutations in Asian patients with advanced non-small-cell lung cancer of adenocarcinoma histology (PIONEER). J Thorac Oncol. 2014;9(2):154-62.

12. El Yacoubi H, Sow ML, Kettani F, Gamra L, Mestari A, Jabri L, et al. Frequency of anaplastic lymphoma kinase rearrangements in Moroccan patients with non small cell lung cancer: a multi-institutional national retrospective study. BMC Cancer. 2020;20(1):479.

13. Lee GD, Lee SE, Oh D-Y, Yu D-B, Jeong HM, Kim J, et al. MET Exon 14 skipping mutations in lung adenocarcinoma: clinicopathologic implications and prognostic values. J Thorac Oncol. 2017;12(8):1233-46.

14. Raman R, Ramamohan V, Vashistha V. P37.30 prevalence of actionable mutations among indian patients with advanced non-small cell lung cancer: a systematic review. J Thorac Oncol. 2021;16(3, Supplement):S454.

15. Ding X, Zhang Z, Jiang T, Li X, Zhao C, Su B, et al. Clinicopathologic characteristics and outcomes of Chinese patients with non-small-cell lung cancer and BRAF mutation. Cancer Med. 2017;6(3):555-62.

16. Wang W-X, Xu C-W, Lei L, Wang X-J, Zhu Y-C, Fang Y, et al. Abstract 38: Large-scale study of NTRK fusions in Chinese solid tumors and using next generation sequencing: A multicenter study. Cancer Res. 2020;80(16 Supplement):38.

17. Mehta A, Saifi M, Batra U, Suryavanshi M, Gupta K. Incidence of ROS1-rearranged non-small-cell lung carcinoma in india and efficacy of crizotinib in lung adenocarcinoma patients. Lung Cancer (Auckl). 2020;11:19-25.

18. Bhaumik S, Ahmad F, Das BR. Somatic mutation analysis of KRAS, BRAF, HER2 and PTEN in EGFR mutation-negative non-small cell lung carcinoma: determination of frequency, distribution pattern and identification of novel deletion in HER2 gene from Indian patients. Med Oncol. 2016;33(10):117.

19. Soria J-C, Ohe Y, Vansteenkiste J, Reungwetwattana T, Chewaskulyong $\mathrm{B}$, Lee KH, et al. Osimertinib in untreated EGFR-mutated advanced nonsmall-cell lung cancer. N Engl J Med. 2017;378(2):113-25.

20. Nakagawa K, Yang JCH, Park K, Ohe Y, Wu YL, Gainor J, et al. 481TiP Checkmate 722: a phase 3 trial of nivolumab with chemotherapy or ipilimumab vs chemotherapy in epidermal growth factor receptor (EGFR)-mutation, T790M-negative stage IV or recurrent non-small cell lung cancer (NSCLC) after EGFR tyrosine kinase inhibitor (TKI) therapy. Ann Oncol. 2016;27:ix154-5.

21. Riely G, Hui R, Carbone D, Park K, Carrigan M, Xu X, et al. P1.01-81 phase 3 study of pemetrexed-platinum with or without pembrolizumab for TKI-resistant/EGFR-mutated advanced NSCLC: KEYNOTE-789. J Thorac Oncol. 2018;13(10, Supplement):S494.

22. Nagano T, Tachihara M, Nishimura Y. Mechanism of resistance to epidermal growth factor receptor-tyrosine kinase inhibitors and a potential treatment strategy. Cells. 2018;7(11):212.

23. Ahn MJ, Han JY, Lee KH, Kim SW, Kim DW, Lee YG, et al. Lazertinib in patients with EGFR mutation-positive advanced non-small-cell lung cancer: results from the dose escalation and dose expansion parts of a first-in-human, open-label, multicentre, phase 1-2 study. Lancet Oncol. 2019;20(12):1681-90.

24. Park K, Jänne PA, Kim D-W, Han J-Y, Wu M-F, Lee J-S, et al. Olmutinib in T790M-positive non-small cell lung cancer after failure of first-line epidermal growth factor receptor-tyrosine kinase inhibitor therapy: a global, phase 2 study. Cancer. 2021;127(9):1407-16.

25. Tan DS, Leighl NB, Riely GJ, Yang JC, Sequist LV, Wolf J, et al. Safety and efficacy of nazartinib (EGF816) in adults with EGFR-mutant 
non-small-cell lung carcinoma: a multicentre, open-label, phase 1 study. Lancet Respir Med. 2020;8(6):561-72.

26. Tan DS-W, Leighl NB, Yang JC-H, Riely GJ, Sequist LV, Toyozawa R, et al. Nazartinib (EGF816) in patients with treatment-naïve EGFR-mutant non-small cell lung cancer (NSCLC): updated phase II results. J Clin Oncol. 2020;38(15_suppl):9574.

27. Shi Y, Hu X, Zhang S, Lv D, Zhang Y, Yu Q, et al. Efficacy and safety of alflutinib (AST2818) in patients with T790M mutation-positive NSCLC: a phase llb multicenter single-arm study. J Clin Oncol. 2020;38(15_suppl):9602.

28. Schalm SS, Dineen T, Lim SM, Park CW, Hsieh J, Woessner R, et al. 1296P BLU-945, a highly potent and selective 4th generation EGFR TKI for the treatment of EGFRT790M/C797S resistant NSCLC. Ann Oncol. 2020;31:S839.

29. Wang S, Song Y, Liu D. EAI045: The fourth-generation EGFR inhibitor overcoming T790M and C797S resistance. Cancer Lett. 2017;385:51-4.

30. Black Diamond Therapeutics IAJ, 2020. BDTX-189: a mutation spectrumselective, oral, irreversible TKI.

31. Schram AM, Ahnert JR, Patel MR, Jauhari S, Sachdev JC, Zhu VW, et al. Safety and preliminary efficacy from the phase 1 portion of MasterKey-01: a First-in-human dose-escalation study to determine the recommended phase 2 dose (RP2D), pharmacokinetics (PK) and preliminary antitumor activity of BDTX-189, an inhibitor of allosteric ErbB mutations, in patients (pts) with advanced solid malignancies. J Clin Oncol. 2021;39(15_suppl):3086.

32. Piotrowska Z, Planchard D, Clancy M, Witter D, Zawel L, Yu H. P1.01-89 a multicenter phase 1/2a trial of CLN-081 in NSCLC with EGFR exon 20 insertion mutations. J Thorac Oncol. 2019;14(10, Supplement):S395.

33. Piotrowska Z, Yu HA, Yang JC-H, Koczywas M, Smit EF, Tan DS-W, et al. Safety and activity of CLN-081 (TAS6417) in NSCLC with EGFR Exon 20 insertion mutations (Ins20). J Clin Oncol. 2021;39(15_suppl):9077.

34. Xu Y, Zhang L, Zhu L, Wang Y, Wang M, Yang Z. Abstract 3081: DZD9008, an oral, wild type selective EGFR inhibitor for the treatment of nonsmall-cell lung cancer with Exon20 insertion and other activating mutations. Cancer Res. 2019:79(13 Supplement):3081.

35. Yang JC-H, Wang M, Mitchell P, Fang J, Nian W, Chiu C-H, et al. Preliminary safety and efficacy results from phase 1 studies of DZD9008 in NSCLC patients with EGFR Exon20 insertion mutations. J Clin Oncol. 2021;39(15_suppl):9008.

36. Liu SV, Villaruz LC, Lee VHF, Zhu VW, Baik CS, Sacher A, et al. LBA61 First analysis of RAIN-701: Study of tarloxotinib in patients with non-small cell lung cancer (NSCLC) EGFR Exon 20 insertion, HER2-activating mutations \& other solid tumours with NRG1/ERBB gene fusions. Ann Oncol. 2020;31:S1189.

37. Park K, John T, Kim S-W, Lee JS, Shu CA, Kim D-W, et al. Amivantamab (JNJ-61186372), an anti-EGFR-MET bispecific antibody, in patients with EGFR exon 20 insertion (exon20ins)-mutated non-small cell lung cancer (NSCLC). J Clin Oncol. 2020;38(15_suppl):9512.

38. FDA approves first targeted therapy for subset of non-small cell lung cancer. News release. FDA. May 21, 2021. Accessed 21 May 2021. https://prn.to/3hOrU1t.

39. Le X, Garassino MC, Cornelissen R, Socinski MA, Tchekmedyian N, Molina JR, et al. CNS activity of poziotinib in NSCLC with exon 20 insertion mutations. J Clin Oncol. 2021;39(15_suppl):9093.

40. Ramalingam SS, Zhou C, Kim TM, Kim S-W, Yang JC-H, Riely GJ, et al. Mobocertinib (TAK-788) in EGFR exon 20 insertion (ex20ins) + metastatic NSCLC ( $\mathrm{MNSCLC}$ ): additional results from platinum-pretreated patients (pts) and EXCLAIM cohort of phase 1/2 study. J Clin Oncol. 2021;39(15_suppl):9014.

41. Haura EB, Cho BC, Lee JS, Han J-Y, Lee KH, Sanborn RE, et al. JNJ61186372 (JNJ-372), an EGFR-cMet bispecific antibody, in EGFRdriven advanced non-small cell lung cancer (NSCLC). J Clin Oncol. 2019;37(15_suppl):9009.

42. Bauml J, Cho BC, Park K, Lee KH, Cho EK, Kim D-W, et al. Amivantamab in combination with lazertinib for the treatment of osimertinibrelapsed, chemotherapy-naïve EGFR mutant (EGFRm) non-small cell lung cancer (NSCLC) and potential biomarkers for response. J Clin Oncol. 2021;39(15_suppl):9006.

43. Sequist LV, Han JY, Ahn MJ, Cho BC, Yu H, Kim SW, et al. Osimertinib plus savolitinib in patients with EGFR mutation-positive, MET-amplified, non-small-cell lung cancer after progression on EGFR tyrosine kinase inhibitors: interim results from a multicentre, open-label, phase $1 \mathrm{~b}$ study. Lancet Oncol. 2020;21(3):373-86.

44. Zhu VW, Bestvina CM, Lopes G, Hamm JT, Johnson ML, Lammers $P E$, et al. Phase II two-arm study of tepotinib plus osimertinib in patients with EGFR-mutant NSCLC and acquired resistance to firstline osimertinib due to MET amplification: INSIGHT 2. J Clin Oncol. 2021;39(15_suppl):TPS9136-TPS.

45. Nakagawa K, Garon EB, Seto T, Nishio M, Ponce Aix S, Paz-Ares L, et al. Ramucirumab plus erlotinib in patients with untreated, EGFRmutated, advanced non-small-cell lung cancer (RELAY): a randomised, double-blind, placebo-controlled, phase 3 trial. Lancet Oncol. 2019;20(12):1655-69.

46. Lilly's CYRAMZA ${ }^{\circledR}$ (ramucirumab) receives FDA approval as first-line treatment for metastatic EGFR-mutated non-small cell lung cancer. News release. Eli Lilly and Company. May 29, 2020. Accessed 30 May 2020. https://bit.ly/2zKc9ol.

47. Akamatsu H, Toi Y, Hayashi H, Fujimoto D, Tachihara M, Furuya N, et al. Efficacy of osimertinib plus bevacizumab vs osimertinib in patients with EGFRT790M-mutated non-small cell lung cancer previously treated with epidermal growth factor receptor-tyrosine kinase inhibitor: West Japan Oncology Group 8715L phase 2 randomized clinical trial. JAMA Oncol. 2021;7(3):386-94

48. Nakahara Y, Kato T, Isomura R, Seki N, Furuya N, Naoki K, et al. A multicenter, open label, randomized phase II study of osimertinib plus ramucirumab versus osimertinib alone as initial chemotherapy for EGFR mutation-positive non-squamous non-small cell lung cancer: TORG1833. J Clin Oncol. 2019;37(15_suppl):TPS9120-TPS.

49. Yu HA, Paz-Ares LG, Yang JC, Lee KH, Garrido P, Park K, et al. Phase 1 study of the efficacy and safety of ramucirumab in combination with osimertinib in advanced T790M-positive EGFR-mutant non-small cell lung cancer. Clin Cancer Res. 2020.

50. Shaw AT, Yeap BY, Mino-Kenudson M, Digumarthy SR, Costa DB, Heist RS, et al. Clinical features and outcome of patients with non-small-cell lung cancer who harbor EML4-ALK. J Clin Oncol. 2009;27(26):4247-53.

51. Camidge DR, Kim HR, Ahn MJ, Yang JCH, Han JY, Hochmair MJ, et al. Brigatinib versus crizotinib in advanced ALK inhibitor-naive ALKpositive non-small cell lung cancer: second interim analysis of the phase III ALTA-1L trial. J Clin Oncol. 2020;38(31):3592-603.

52. Shaw AT, Bauer TM, de Marinis F, Felip E, Goto Y, Liu G, et al. First-line lorlatinib or crizotinib in advanced ALK-positive lung cancer. N Engl J Med. 2020;383(21):2018-29.

53. Yang J-J, Zhou J, Yang N, Wu Z, Sun J, Hui A-M, et al. SAF-189s in previously treated patients with advanced ALK-rearranged non-small cell lung cancer (NSCLC): results from the dose-finding portion in a single-arm, first-in-human phase I/II study. J Clin Oncol. 2020;38(15_suppl):e21689-e.

54. Fang Y, Pan H, Lu S, Hu H, Lu Q. A phase I study to evaluate safety, tolerability, pharmacokinetics, and preliminary antitumor activity of TQ-B3101. J Clin Oncol. 2020;38(15_suppl):e21705-e.

55. Cui JJ, Rogers E, Zhai D, Deng W, Ung J, Nguyen V, et al. Abstract 5226: TPX-0131: A next generation macrocyclic ALK inhibitor that overcomes ALK resistant mutations refractory to current approved ALK inhibitors. Can Res. 2020:80(16 Supplement):5226.

56. Selvaggi G, Wakelee HA, MokT, Wu YL, Reck M, Chiappori A, et al. ID:1882 phase III randomized study of ensartinib vs crizotinib in anaplastic lymphoma kinase (ALK) POSITIVE NSCLC patients: eXalt3. J Thorac Oncol. 2020;15(10, Supplement):e41-2.

57. Huang Z, Xiong Q, Cui Z, Tao H, Zhang S, Wang L, et al. Efficacy and safety of crizotinib plus bevacizumab in ALK/ROS-1/c-MET positive non-small cell lung cancer: an open-label, single-arm, prospective observational study. Am J Transl Res. 2021;13(3):1526-34.

58. Vansteenkiste JF, Van De Kerkhove C, Wauters E, Van Mol P. Capmatinib for the treatment of non-small cell lung cancer. Expert Rev Anticancer Ther. 2019;19(8):659-71.

59. Wolf J, Seto T, Han JY, Reguart N, Garon EB, Groen HJM, et al. Capmatinib in MET exon 14-mutated or MET-amplified non-small-cell lung cancer. N Engl J Med. 2020;383(10):944-57.

60. Wolf J, Overbeck TR, Han J-Y, Hochmair M, de Marinis F, Ohashi K, et al. Capmatinib in patients with high-level MET-amplified advanced non-small cell lung cancer (NSCLC): results from the phase 2 GEOMETRY mono-1 study. J Clin Oncol. 2020;38(15_suppl):9509. 
61. Wolf J, Garon EB, Groen HJM, Tan DS-W, Robeva A, LeMouhaer $\mathrm{S}$, et al. Capmatinib in MET exon 14-mutated, advanced NSCLC: Updated results from the GEOMETRY mono-1 study. J Clin Oncol. 2021;39(15_suppl):9020.

62. Patel JD, Le X, Veillon R, Anderson IC, Bestvina CM, Demedts I, et al. Intracranial activity of tepotinib in patients (pts) with MET exon 14 (METex14) skipping NSCLC enrolled in VISION. J Clin Oncol. 2021;39(15_suppl):9084.

63. Paik PK, Felip E, Veillon R, Sakai H, Cortot AB, Garassino MC, et al. Tepotinib in non-small-cell lung cancer with MET exon 14 skipping mutations. N Engl J Med. 2020;383(10):931-43.

64. Le X, Paz-Ares LG, Van Meerbeeck J, Viteri S, CabreraGalvez C, VicenteBaz D, et al. Tepotinib in patients (pts) with advanced non-small cell lung cancer (NSCLC) with MET amplification (METamp). J Clin Oncol. 2021;39(15_suppl):9021.

65. Camidge DR, Janku F, Martinez-Bueno A, Catenacci DVT, Lee J, Lee $\mathrm{S}-\mathrm{H}$, et al. Safety and preliminary clinical activity of the MET antibody mixture, Sym015 in advanced non-small cell lung cancer (NSCLC) patients with MET amplification/exon 14 deletion (METAmp/Ex14 $\Delta$ ). J Clin Oncol. 2020;38(15_suppl):9510.

66. Salgia R, Sattler M, Scheele J, Stroh C, Felip E. The promise of selective MET inhibitors in non-small cell lung cancer with MET exon 14 skipping. Cancer Treat Rev. 2020;87:102022.

67. Rowlands T, Boyapati A, Li S, Daly C, Seebach FA, Lowy I, et al. A phase I/II study of REGN5093, a MET x MET bispecific antibody, in patients with MET-altered advanced non-small cell lung cancer (NSCLC). J Clin Oncol. 2020;38(15):TPS9628-TPS.

68. Gainor JF, Shaw AT. Novel targets in non-small cell lung cancer: ROS1 and RET fusions. Oncologist. 2013;18(7):865-75.

69. Drilon A, Lin JJ, Filleron T, Ni A, Milia J, Bergagnini I, et al. Frequency of brain metastases and multikinase inhibitor outcomes in patients with RET-rearranged lung cancers. J Thorac Oncol. 2018;13(10):1595-601.

70. Drilon A, Oxnard GR, Tan DSW, Loong HHF, Johnson M, Gainor J, et al. Efficacy of selpercatinib in RET fusion-positive non-small-cell lung cancer. N Engl J Med. 2020;383(9):813-24.

71. Besse B, Drilon AE, Solomon BJ, Subbiah V, Tan DS-W, Park K, et al. Updated overall efficacy and safety of selpercatinib in patients (pts) with RET fusion + non-small cell lung cancer (NSCLC). J Clin Oncol. 2021;39(15_suppl):9065.

72. Gainor JF, Curigliano G, Kim D-W, Lee DH, Besse B, Baik CS, et al. Registrational dataset from the phase I/II ARROW trial of pralsetinib (BLU-667) in patients (pts) with advanced RET fusion+ non-small cell lung cancer (NSCLC). J Clin Oncol. 2020;38(15_suppl):9515.

73. Curigliano G, Gainor JF, Griesinger F, Thomas M, Subbiah V, Baik CS, et al. Safety and efficacy of pralsetinib in patients with advanced RET fusionpositive non-small cell lung cancer: update from the ARROW trial. J Clin Oncol. 2021;39(15_suppl):9089.

74. Drilon AE, Zhai D, Rogers E, Deng W, Zhang X, Ung J, et al. The nextgeneration RET inhibitor TPX-0046 is active in drug-resistant and naïve RET-driven cancer models. J Clin Oncol. 2020;38(15_suppl):3616.

75. Schoffski P, Aftimos PG, Massard C, Italiano A, Jungels C, Andreas K, et al. A phase I study of BOS172738 in patients with advanced solid tumors with RET gene alterations including non-small cell lung cancer and medullary thyroid cancer. J Clin Oncol. 2019;37(15_suppl):52.

76. Schoffski P, Cho BC, Italiano A, Loong HHF, Massard C, Medina Rodriguez L, et al. BOS172738, a highly potent and selective RET inhibitor, for the treatment of RET-altered tumors including RET-fusion+ NSCLC and RET-mutant MTC: phase 1 study results. J Clin Oncol. 2021;39(15_suppl):3008.

77. Sanchez JN, Wang T, Cohen MS. BRAF and MEK inhibitors: use and resistance in BRAF-mutated cancers. Drugs. 2018;78(5):549-66.

78. Planchard D, Smit EF, Groen HJM, Mazieres J, Besse B, Helland Å, et al. Dabrafenib plus trametinib in patients with previously untreated BRAFV600E-mutant metastatic non-small-cell lung cancer: an openlabel, phase 2 trial. Lancet Oncol. 2017;18(10):1307-16.

79. Janku F, Iyer G, Spreafico A, Yamamoto N, Bang Y-J, Elez E, et al. A phase I study of LXH254 in patients (pts) with advanced solid tumors harboring MAPK pathway alterations. J Clin Oncol. 2018;36(15_suppl):2586.

80. Bergethon K, Shaw AT, Ou SH, Katayama R, Lovly CM, McDonald NT, et al. ROS1 rearrangements define a unique molecular class of lung cancers. J Clin Oncol. 2012;30(8):863-70.
81. Drilon A, Siena S, Dziadziuszko R, Barlesi F, Krebs MG, Shaw AT, et al. Entrectinib in ROS1 fusion-positive non-small-cell lung cancer: integrated analysis of three phase 1-2 trials. Lancet Oncol. 2020;21 (2):261-70.

82. Shaw AT, Solomon BJ, Besse B, Bauer TM, Lin C-C, Soo RA, et al. ALK resistance mutations and efficacy of lorlatinib in advanced anaplastic lymphoma kinase-positive non-small-cell lung cancer. J Clin Oncol. 2019;37(16):1370-9.

83. Doebele RC, Lin JJ, Nagasaka M, Zhu VW, Gabrail NY, Bazhenova $L$, et al. TRIDENT-1: a global, multicenter, open-label Phase II study investigating the activity of repotrectinib in advanced solid tumors harboring ROS1 or NTRK1-3 rearrangements. J Clin Oncol. 2020;38(15_suppl):TPS9637-TPS.

84. Ou S-HI, Fujiwara Y, Shaw AT, Yamamoto N, Nakagawa K, Fan F, et al. Efficacy of taletrectinib (AB-106/DS-6051 b) in ROS1 + NSCLC: an updated pooled analysis of U.S. and Japan phase 1 studies. JTO Clin Res Rep. 2021;2(1):100108.

85. Zhou C, Fan H, Wang Y, Wu H, Yang N, Li K, et al. Taletrectinib (AB106; DS-6051 b) in metastatic non-small cell lung cancer (NSCLC) patients with ROS1 fusion: preliminary results of TRUST. J Clin Oncol. 2021;39(15_suppl):9066.

86. Farago AF, Le LP, Zheng Z, Muzikansky A, Drilon A, Patel M, et al. Durable clinical response to entrectinib in NTRK1-rearranged non-small cell lung cancer. J Thorac Oncol. 2015;10(12):1670-4.

87. Hong DS, DuBois SG, Kummar S, Farago AF, Albert CM, Rohrberg KS, et al. Larotrectinib in patients with TRK fusion-positive solid tumours: a pooled analysis of three phase 1/2 clinical trials. Lancet Oncol. 2020;21(4):531-40.

88. Lassen U. Entrectinib for ROS1 fusion-positive NSCLC and NTRK fusionpositive solid tumours. Lancet Oncol. 2020;21(2):193-4.

89. Chung V, Wang L, Fletcher MS, Massarelli E, Cristea MC, Kamaraju S, et al. First-time in-human study of VMD-928, an oral allosteric TrkA selective inhibitor targeting TrkA protein overexpression, in patients with solid tumors or lymphoma. J Clin Oncol. 2021;39(15_suppl):3081.

90. Simanshu DK, Nissley DV, McCormick F. RAS proteins and their regulators in human disease. Cell. 2017;170(1):17-33.

91. Nadal E, Chen G, Prensner JR, Shiratsuchi H, Sam C, Zhao L, et al. KRASG12C mutation is associated with poor outcome in surgically resected lung adenocarcinoma. J Thorac Oncol. 2014;9(10):1513-22.

92. Biernacka A, Tsongalis PD, Peterson JD, de Abreu FB, Black CC, Gutmann EJ, et al. The potential utility of re-mining results of somatic mutation testing: KRAS status in lung adenocarcinoma. Cancer Genet. 2016;209(5):195-8.

93. Skoulidis F, Li BT, Dy GK, Price TJ, Falchook GS, Wolf J, et al. Sotorasib for lung cancers with KRAS p.G12C mutation. N Engl J Med. 2021.

94. Skoulidis F, Li BT, Govindan R, Dy GK, Shapiro G, Bauml J, et al. Overall survival and exploratory subgroup analyses from the phase 2 CodeBreaK 100 trial evaluating sotorasib in pretreated KRAS p.G12C mutated non-small cell lung cancer. J Clin Oncol. 2021;39(15_suppl):9003.

95. FDA approves first targeted therapy for lung cancer mutation previously considered resistant to drug therapy. News release. FDA. May 28, 2021. Accessed 28 May 2021. https://bit.ly/3fwHwVG.

96. Papadopoulos KP, Ou S-HI, Johnson ML, Christensen J, Velastegui K, Potvin D, et al. A phase I/I multiple expansion cohort trial of MRTX849 in patients with advanced solid tumors with KRAS G12C mutation. J Clin Oncol. 2019;37(15_suppl):TPS3161-TPS.

97. Jänne PA, Rybkin II, Spira Al, Riely GJ, Papadopoulos KP, Sabari JK, et al. 3LBA late breaking-KRYSTAL-1: activity and safety of adagrasib (MRTX849) in advanced/metastatic non-small-cell lung cancer (NSCLC) harboring KRAS G12C mutation. Eur J Cancer. 2020;138:S1-2.

98. MokTSK, Lawler WE, Shum MK, Dakhil SR, Spira Al, Barlesi F, et al. KRYSTAL-12: a randomized phase 3 study of adagrasib (MRTX849) versus docetaxel in patients (pts) with previously treated non-smallcell lung cancer (NSCLC) with KRASG12C mutation. J Clin Oncol. 2021;39(15_suppl):TPS9129-TPS.

99. Janne PA, Yu HA, Johnson ML, Steuer CE, Vigliotti M, lacobucci C, et al. Safety and preliminary antitumor activity of U3-1402: a HER3-targeted antibody drug conjugate in EGFR TKI-resistant, EGFRm NSCLC. J Clin Oncol. 2019;37(15_suppl):9010.

100. Janne PA, Baik CS, Su W-C, Johnson ML, Hayashi H, Nishio M, et al. Efficacy and safety of patritumab deruxtecan (HER3-DXd) in EGFR 
inhibitor-resistant, EGFR-mutated (EGFRm) non-small cell lung cancer (NSCLC). J Clin Oncol. 2021;39(15_suppl):9007.

101. Schaefer ES, Camidge DR, Yoh K, Zer A, Hernandez Guerrero T, Bar $J$, et al. A phase $1 \mathrm{~b}$, open-label, single-arm study of cofetuzumab pelidotin (a PTK7-targeting antibody-drug conjugate) in patients with PTK7-expressing, recurrent non-small cell lung cancer (NSCLC). J Clin Oncol. 2021;39(15_suppl):TPS3142-TPS.

102. Damelin M, Bankovich A, Bernstein J, Lucas J, Chen L, Williams S, et al. A PTK7-targeted antibody-drug conjugate reduces tumor-initiating cells and induces sustained tumor regressions. Sci Transl Med. 2017;9(372):eaag2611.

103. Sachdev JC, Maitland ML, Sharma M, Moreno V, Boni V, Kummar S, et al. PF-06647020 (PF-7020), an antibody-drug conjugate (ADC) targeting protein tyrosine kinase 7 (PTK7), in patients (pts) with advanced solid tumors: Results of a phase I dose escalation and expansion study. J Clin Oncol. 2018;36(15_suppl):5565.

104. Gazzah A, Ricordel C, Cousin S, Cho BC, Calvo E, Kim TM, et al. Efficacy and safety of the antibody-drug conjugate (ADC) SAR408701 in patients (pts) with non-squamous non-small cell lung cancer (NSQ NSCLC) expressing carcinoembryonic antigen-related cell adhesion molecule 5 (CEACAM5). J Clin Oncol. 2020;38(15_suppl):9505.

105. Spira A, Lisberg A, Sands J, Greenberg J, Phillips P, Guevara F, et al. OA03.03 datopotamab deruxtecan (Dato-DXd; DS-1062), a TROP2 ADC, in patients with advanced NSCLC: updated results of TROPION-PanTumor01 phase 1 study. J Thorac Oncol. 2021;16(3, Supplement):S106-7.

106. Yoh K, Goto Y, Thomas M, Spira Al, Sands J, Johnson ML, et al. A randomized, phase 3 study of datopotamab deruxtecan (Dato-DXd; DS-1062) versus docetaxel in previously treated advanced or metastatic non-small cell lung cancer (NSCLC) without actionable genomic alterations (TROPION-Lung01). J Clin Oncol. 2021;39(15_suppl):TPS9127-TPS.

107. Powderly JD, Jang S, Lohr J, Spira Al, Bohac GC, Sharma M. Preliminary dose escalation results from a phase $\mathrm{I} / \mathrm{ll}$, first-in-human study of MGC018 (anti-B7-H3 antibody-drug conjugate) in patients with advanced solid tumors. J Clin Oncol. 2020;38(15_suppl):3071.

108. Scheffler M, Bos M, Gardizi M, König K, Michels S, Fassunke J, et al. PIK3CA mutations in non-small cell lung cancer (NSCLC): genetic heterogeneity, prognostic impact and incidence of prior malignancies. Oncotarget. 2015;6(2):1315-26.

109. Dobashi Y, Suzuki S, Matsubara H, Kimura M, Endo S, Ooi A. Critical and diverse involvement of Akt/mammalian target of rapamycin signaling in human lung carcinomas. Cancer. 2009;115(1):107-18.

110. Dobashi Y, Watanabe Y, Miwa C, Suzuki S, Koyama S. Mammalian target of rapamycin: a central node of complex signaling cascades. Int I Clin Exp Pathol. 2011;4(5):476-95.
111. Dobashi Y, Koyama S, Kanai Y, Tetsuka K. Kinase-driven pathways of EGFR in lung carcinomas: perspectives on targeting therapy. Front Biosci (Landmark Ed). 2011;16:1714-32.

112. Paik PK, Ahn LSH, Plodkowski AJ, Fan P-D, Rudin CM. Phase II study of TAK228 in patients with advanced non-small cell lung cancer (NSCLC) harboring NFE2L2 and KEAP1 mutations. J Clin Oncol. 2020;38(15_suppl):9607.

113. Yoo YJ, Kim H, Park SR, Yoon YJ. An overview of rapamycin: from discovery to future perspectives. J Ind Microbiol Biotechnol. 2017:44(4):537-53.

114. Janku F. Phosphoinositide 3-kinase (PI3K) pathway inhibitors in solid tumors: From laboratory to patients. Cancer Treat Rev. 2017;59:93-101.

115. Jiang J, Yang YC, Schulze CJ, Evans JW, Wang ZC, Lee BJ, et al. Optimal therapeutic positioning of a selective bi-steric inhibitor of MTORC1 in genetically defined cancers. Eur J Cancer. 2020;138S2:S1-62.

116. Comprehensive molecular profiling of lung adenocarcinoma. Nature. 2014;511(7511):543-50.

117. Li BT, Shen R, Buonocore D, Olah ZT, Ni A, Ginsberg MS, et al. Adotrastuzumab emtansine for patients with HER2-mutant lung cancers: results from a phase II basket trial. J Clin Oncol. 2018;36(24):2532-7.

118. Smit EF, Nakagawa K, Nagasaka M, Felip E, Goto Y, Li BT, et al. Trastuzumab deruxtecan (T-DXd; DS-8201) in patients with HER2-mutated metastatic non-small cell lung cancer (NSCLC): interim results of DESTINY-Lung01. J Clin Oncol. 2020;38(15_suppl):9504.

119. Mazieres J, Lafitte C, Ricordel C, Greillier L, Pujol J-L, Zalcman G, et al. Combination of trastuzumab, pertuzumab and docetaxel in patients with advanced non-small cell lung cancer (NSCLC) harboring HER2 mutation: final results from the IFCT-1703 R2D2 trial. J Clin Oncol. 2021;39(15_suppl):9015.

120. Garcia Fortanet J, Chen CH, Chen YN, Chen Z, Deng Z, Firestone B, et al. Allosteric inhibition of SHP2: identification of a potent, selective, and orally efficacious phosphatase inhibitor. J Med Chem. 2016;59(17):7773-82.

121. LaMarche MJ, Acker M, Argintaru A, Bauer D, Boisclair J, Chan H, et al. Identification of TNO155, an Allosteric SHP2 Inhibitor for the Treatment of Cancer. J Med Chem. 2020;63(22):13578-94.

122. Falchook GS, Patel MR, Yap TA, McEachern K, Kuplast-Barr K, Utley $L$, et al. A first-in-human phase 1 study of a novel PARP7 inhibitor RBN-2397 in patients with advanced solid tumors. J Clin Oncol. 2021;39(15_suppl):3000.

\section{Publisher's Note}

Springer Nature remains neutral with regard to jurisdictional claims in published maps and institutional affiliations.
Ready to submit your research? Choose BMC and benefit from:

- fast, convenient online submission

- thorough peer review by experienced researchers in your field

- rapid publication on acceptance

- support for research data, including large and complex data types

- gold Open Access which fosters wider collaboration and increased citations

- maximum visibility for your research: over $100 \mathrm{M}$ website views per year

At BMC, research is always in progress.

Learn more biomedcentral.com/submissions 